\title{
Coastal lowland and floodplain evolution along the lower reaches of the Supsa River (western Georgia)
}

\author{
Hannes Laermanns ${ }^{1}$, Simon Matthias May ${ }^{1}$, Daniel Kelterbaum ${ }^{1}$, Giorgi Kirkitadze $^{2}$, Stephan Opitz $^{1}$, \\ Levan Navrozashvili ${ }^{2}$, Mikheil Elashvili ${ }^{2}$, and Helmut Brückner ${ }^{1}$ \\ ${ }^{1}$ Institute of Geography, University of Cologne, Albertus-Magnus-Platz, 50923 Cologne, Germany \\ ${ }^{2}$ Ilia State University, K. Cholokashvili Ave 3/5, Tbilisi 0162, Georgia
}

Correspondence: Hannes Laermanns (h.laermanns@uni-koeln.de) and Helmut Brückner (h.brueckner@uni-koeln.de)

Relevant dates: $\quad$ Received: 5 December 2018 - Revised: 21 May 2019 - Accepted: 30 May 2019 Published: 24 July 2019

How to cite:

Laermanns, H., May, S. M., Kelterbaum, D., Kirkitadze, G., Opitz, S., Navrozashvili, L., Elashvili, M., and Brückner, H.: Coastal lowland and floodplain evolution along the lower reaches of the Supsa River (western Georgia), E\&G Quaternary Sci. J., 68, 119-139, https://doi.org/10.5194/egqsj-68-1192019, 2019.

Abstract:

In the southernmost part of the Colchian plain (Georgia), the Supsa and Rioni rivers represent important catchments for reconstructing Holocene landscape changes. Using granulometric methods, geochemical analyses and radiocarbon dating, we demonstrate that significant palaeoenvironmental changes have taken place in the surroundings of the Supsa fan since at least 4000 BCE. The initial foothill fan accumulation was prolonged by delta plain progradation. Due to continued fluvial sediment supply, mainly from the Rioni, the lagoon silted up and extended peat bogs formed east of the beach ridge complex. The Supsa fan first prograded northwards (since the third millennium BCE) and later shifted westwards, eventually following an avulsion of the Rioni. While Supsa deposits remain limited to the area of the fan and the modern estuary, the alluvial fines of the Rioni dominate the surrounding areas. The relative sea-level (RSL) index points of the region suggest a gradual RSL rise from $\sim-9 \mathrm{~m}$ between 4000 and $3500 \mathrm{BCE}$ to $-3 /-2 \mathrm{~m}$ below the modern sea level in the second half of the first millennium BCE, the period during which Greek colonization and Colchian settlements are attested by archaeological remains.

Kurzfassung: $\quad$ Im südlichsten Teil der kolchischen Tiefebene (Georgien) stellen die Einzugsgebiete von Rioni und Supsa wichtige Areale zur Rekonstruktion des holozänen Landschaftswandels dar. Mittels granulometrischer und geochemischer Analysen sowie Radiokohlenstoffdatierungen lässt sich der signifikante Landschaftswandel im Bereich des Supsa-Schwemmfächers seit etwa 4000 v. Chr. nachweisen. Das Areal wurde von einer Sandbarre vom offenen Meer getrennt, hinter der sich große Stillwasserbereiche bildeten. Der anhaltende fluviale Sedimenteintrag, hauptsächlich durch den Rioni, begünstigte die allmähliche Verlandung und die Entstehung von Torfmooren. Gleichzeitig baute sich - zunächst nach Norden (etwa ab dem 3. Jahrtausend v. Chr.) und später durch den Rioni nach Westen abgelenkt - der Schwemmfächer des Supsa vor. Während sich die Supsa-Ablagerungen im Wesentlichen auf den Schwemmfächer und die aktuelle Mündung beschränken, dominieren die feinkörnigen Ablagerungen des Rioni die Umgebung. Die Indexpunkte für den relativen Meeresspiegel deuten auf einen anhaltenden Anstieg des Meeres hin, ausgehend von etwa $-9 \mathrm{~m}$ unter dem 
heutigen Niveau um 4000 bis 3500 v. Chr. auf -3 bis $-2 \mathrm{~m}$ in der zweiten Hälfte des 1 . Jahrtausends v. Chr. Für den letztgenannten Zeitraum sind kolchische und griechische Siedlungen durch archäologische Funde in der Umgebung der Supsa-Mündung belegt.

\section{Introduction}

Deltas, estuaries and low-lying coastal plains render important information about the postglacial coastal evolution and the Holocene sea-level rise (Arslanov et al., 2007; Marriner et al., 2010; Haghani et al., 2015). At the same time deltaic regions played an important role for the ancient colonization (e.g. by Greeks, Romans and Phoenicians; Anthony et al., 2014; Giaime et al., 2019), providing access to the hinterland as well as to the open sea. Especially in the Mediterranean many important ancient cities were founded on the coast of large embayments and estuaries, e.g. Troy (Kraft et al., 2003), Ephesus (Stock et al., 2013, 2016), Miletus and Priene (Brückner et al., 2002, 2017) and their respective gulfs, and Aquileia near Laguna di Grado in northeastern Italy (Arnaud-Fassetta et al., 2003).

While a significant amount of research on both sea-level evolution and human-environment interactions exists from Mediterranean coastal lowlands and delta regions (e.g. Lario et al., 2002; Pavlopoulos et al., 2006; Carozza et al., 2011; Brückner et al., 2017; Herda et al., 2019) - many of them in geoarchaeological contexts and at ancient harbour sites especially(Marriner and Morhange, 2007; e.g. for Rome's harbours Portus and Ostia: Delile et al., 2014; Goiran et al., 2014; for Miletus: Brückner et al., 2014; for Alexandria: Flaux et al., 2017; for Ephesus Stock et al., 2013, 2014) studies on the sea-level evolution of the Black Sea are scarce. Only during the last decade, the number of publications has increased for particular areas (e.g. Danube delta: Giosan et al., 2006; Taman and Kerch peninsulas: Kelterbaum et al., 2011, 2012) and in the context of the controversial debate about sea-level evolution and fluctuations (e.g. Brückner et al., 2010; Fouache et al., 2012; Erginal et al., 2013; Bolikhovskaya et al., 2018).

In particular, the Georgian Black Sea coast remains understudied so far, although it stands out with its unique vegetation history and long-time human occupation, with the ancient Kingdom of Colchis and several Greek colonies of which the lost city of Phasis is the most famous (Lordkipanidze, 1991). Overall, the Georgian coast and its central section, the Colchian plain, offer - with estuaries of numerous rivers and extensive wetlands - promising geo-bioarchives. The potential of the Colchian plain (i.e. the area between the rivers Supsa and Enguri, Fig. 1) for palaeoenvironmental and geoarchaeological studies has been shown only in the very recent past by elucidating the mid-Holocene to late Holocene development of the Rioni delta (Laermanns et al., 2017a) and presenting new data on the evolution of Bronze Age settlements (Laermanns et al., 2017b).

While most of the major rivers in the northern and central Colchian plain are sourced in the Greater Caucasus in the north and have formed the vast alluvial Colchian plain, the southernmost river, the Supsa, is fed by the Lesser Caucasus in the south (Fig. 1). While presently flowing into the Black Sea, it has built a prominent, semi-circular alluvial fan at the interface between the mountains and the southern Colchian plain, which constitutes an arable area along the southern margin of Lake Paliastomi (Fig. 2). Colchian and Greek amphorae, as well as graves, were found at several sites in the surroundings of the river course (Lordkipanidze 1985; Miron and Orthmann, 1995; Sens, 2009); thus, the area may have represented a favourable settlement place due to its slightly elevated position near Lake Paliastomi; even speculations on a possible location of Phasis in this area exist (see an overview in Gamkrelidze, 2012). Yet, to date there is neither detailed information about the Holocene evolution of the Supsa fan and its environs nor on its occupation history.

Against this background, the overall aim of our study is to provide the first data on the Holocene evolution of the Supsa alluvial fan and its surroundings during the past millennia. Therefore, we aim to (i) document the chronostratigraphy of the fan, (ii) reconstruct the palaeogeographical and palaeoenvironmental evolution of the delta area, and (iii) differentiate between the sediments originating from the Supsa and the Rioni catchments. Furthermore, we intend to (iv) probe if archaeological findings can testify that the former conditions favoured human occupation in this particular area.

\section{Regional setting}

\subsection{Physical setting}

The Kolkheti lowlands or Colchian plain, which roughly correspond to the historical region of Colchis, form a triangularshaped coastal plain of western Georgia (Fig. 1). They are limited by the Black Sea in the west, the slopes of the Greater Caucasus in the northeast and the Lesser Caucasus in the southeast (Fig. 1). The lower Likhi range connects both Caucasian ranges and forms the easternmost border, separating the Colchian lowlands from the Kura catchment in eastern Georgia, which discharges eastwards into the Caspian Sea (Eppelbaum and Khesin, 2012).

Like the whole of Georgia, the Colchian plain is located in the convergence zone between the Arabian and Eurasian plates (Dhont and Chorowicz, 2006). During the closure of 


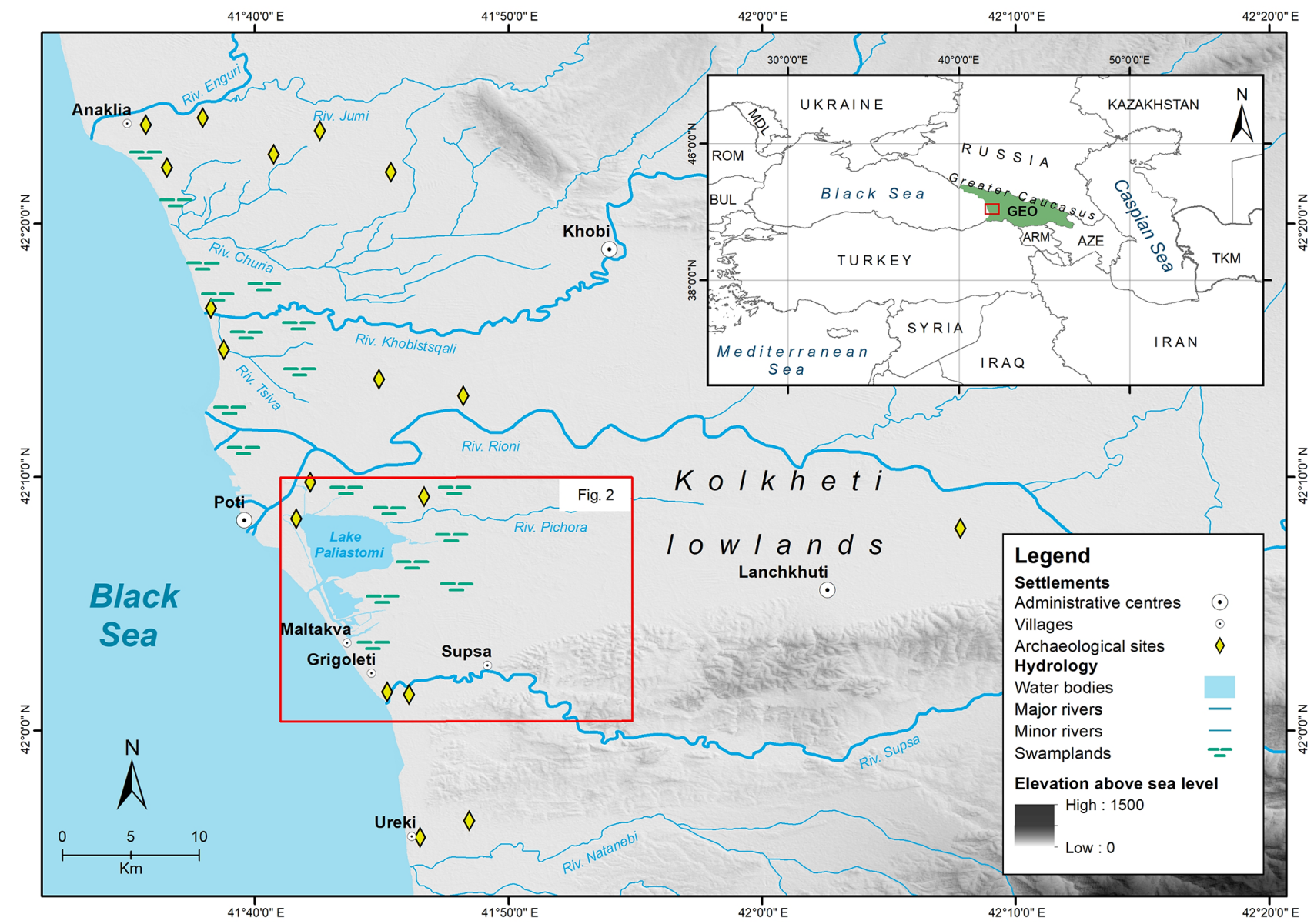

Figure 1. Map of the central part of the Georgian Black Sea coast, also known as Colchian plain or Kolkheti lowlands. It is dominated by a vast alluvial plain, swamplands and several rivers of which the Enguri, Khobistsqali, Rioni and Supsa are the most important. The red frame indicates the area shown in Fig. 2 (based on the ASTER digital elevation model, shaded model).

the northern Neo-Tethys Ocean (Sosson et al., 2010) and the subsequent Alpine-Himalayan orogeny, this former Mesozoic to Cenozoic back-arc marginal extensional basin was closed and the folded mountains of the Caucasus evolved (Adamia et al., 2011; Forte et al., 2014). Triggered by the northward drift of the Arabian plate, the ongoing continentcontinent collision between the Lesser Caucasus arc and the Eurasian basement still has convergence rates between $\sim 12 \mathrm{~mm}$ per year in the eastern part and $\sim 2 \mathrm{~mm}$ per year in the western part, e.g. the Colchian plain (Avdeev and Niemi, 2011; Y1lmaz et al., 2013). There, convergence occurs along the Adjara-Trialeti Thrust Belt (ATTB) in the south and the Chaladidi-Tsaishi Thrust (CTT) in the north (Reilinger et al., 2006; Forte et al., 2014) (Fig. 1).

Though the Caucasus mountains evolved from the same tectonic processes they differ in their geology from the Colchian plain: the Greater Caucasus in the north is a polycyclic, folded-nappe formation (Okrostsvaridze et al., 2016) and consists of a pre-alpine crystalline basement complex and a younger cover of Mesozoic to Neogene ophiolites, (marine) sedimentary and volcanic rocks. The Lesser Caucasus inherits additional andesitic pyroclastica and effusiva (Mitchell and Westaway, 1999), as well as granite and gneiss intrusions (Yilmaz et al., 2013).

In contrast, the Colchian plain primarily consists of Cretaceous and Palaeogene sediments and by volcanoclastics (Bazhenov and Burtman, 2002). These deposits are overlain by Quaternary molasses and river terraces of eroded material from the surrounding mountains and their foothills (Adamia et al., 2011). Due to high fluvial sedimentation and tectonic subsidence, the deposits reach a thickness of up to $30-40 \mathrm{~m}$ in the western area (Adamia et al., 2011). During the Holocene, these deposits and the large-scale sealevel rise dominated the morphology on the Colchian plain. Here, massive coastline changes were provoked, especially by the reconnection of the Black Sea with the Mediterranean Sea $\sim 8400$ years ago (Ryan, 2007; Giosan et al., 2009), and vast areas of former dry land drowned. Probably around $3000 \mathrm{BCE}$, sea level nearly reached its present posi- 


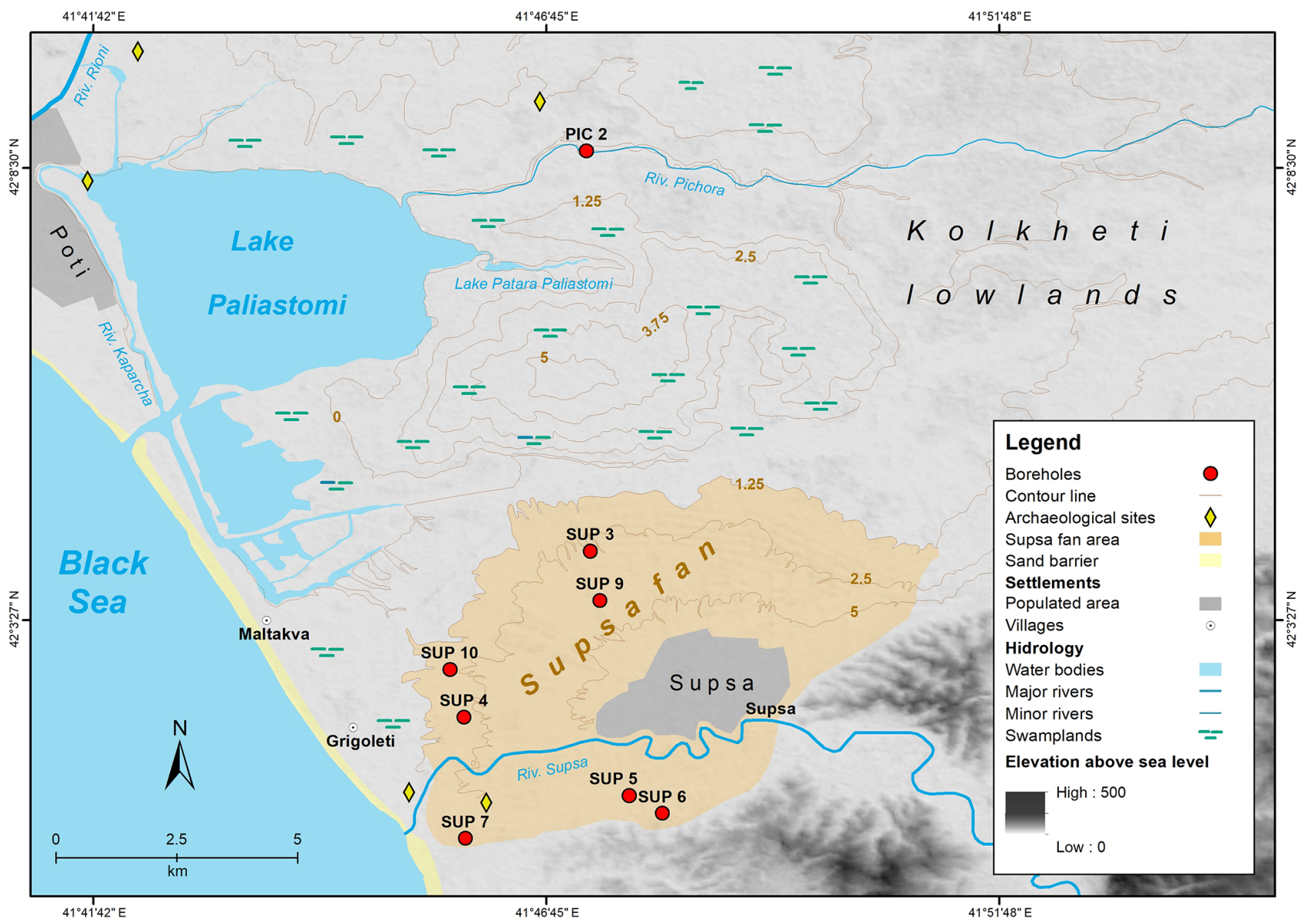

Figure 2. Map of the research area. The Supsa fan is highlighted in light brown. The sites of the boreholes are indicated by red dots (based on the ASTER digital elevation model, shaded model).

tion $(\sim 1.5-0 \mathrm{~m})$ (Brückner et al., 2010; Fouache et al., 2012; Kelterbaum et al., 2012; Laermanns et al., 2017a).

Today, the central plain is dominated by four rivers (from north to south): Enguri, Khobistsqali, Rioni and Supsa. While the former three have their source areas in the Greater Caucasus, the latter originates from the Lesser Caucasus (Fig. 1). While the Rioni has a catchment of ca. $13400 \mathrm{~km}^{2}$, an average water volume of $13.38 \mathrm{~km}^{3} \mathrm{a}^{-1}$ and a sediment load of $6.02 \times 10^{6} \mathrm{ta}^{-1}$ before debouching into the Black Sea (Berkun et al., 2015), the Supsa is considerably smaller: with a catchment of ca. $1100 \mathrm{~km}^{2}$, a discharge of less than $3 \mathrm{~km}^{3} \mathrm{a}^{-1}$ and a sediment load of $0.246 \times 10^{6} \mathrm{ta}^{-1}$, the Supsa can be considered as a river of regional importance only. However, it contributes more water than the two northernmost rivers Enguri and Khobistsqali with 1.25 and $1.89 \mathrm{~km}^{3}$ discharge and catchment areas of 460 and $1340 \mathrm{~km}^{2}$, respectively (Jaoshvili, 2002; Berkun et al., 2015). The sediment load of the Khobisqali is comparable $\left(0.221 \times 10^{6} \mathrm{ta}^{-1}\right)$, and the load of the Enguri is significantly higher $\left(0.45 \times 10^{6} \mathrm{ta}^{-1}\right.$. In general, the sediment load of the four rivers predominantly consists of sand and silt (Jaoshvili, 2002).
The Supsa is the only river which has built a major lobate fan in the Kolkheti lowlands, which in its centre rises up to several metres over the surrounding swamp areas while its outermost edges are of almost the same elevation (Fig. 2). It is located directly north of the foothills where the Supsa discharged into the former lagoon, the recent open plain. This protected location may be the reason why the sediments were not affected by longshore drift and, therefore, not transported further along the coast. In this paper, the term "Supsa fan" refers to this morphological feature. In contrast, the recent river mouth of the Supsa is located further to the west, forming an estuary which is comparable to those of the Enguri and Khobistsqali rivers.

The Colchis shelf is only $10-15 \mathrm{~km}$ wide. It is dissected by submarine canyons that were formed during sea-level lowstands and are extensions of the (later) estuaries of Supsa, Rioni and Enguri (Jaoshvili, 2002). While the dominant coastal surface current runs anti-clockwise, annual fluctuations occur especially in front of the Rioni delta (Jaoshvili, 2002; Korotaev et al., 2003). During the last millennia, the long-shore 
drift has formed the wave-dominated Colchian coastline with long-stretched, wide sandy beaches.

The regional climate is characterized by high precipitation ( $>2000 \mathrm{~mm}$ per year) and average annual temperatures around $14{ }^{\circ} \mathrm{C}$, without regular winter frosts (the mean January temperature is $6^{\circ} \mathrm{C}$ in Batumi) (Box et al., 2000; see also Denk et al., 2000; Hijmans et al., 2005). This warm and humid climate, combined with the high relief in the upper river courses, led to high rates of weathering and erosion, which in turn result in the high sediment load of the rivers.

Extensive wetlands with swamps, peat bogs, shallow lakes, open reed areas and forests of evergreen understory cover huge parts of the Colchian plain, while mixed forests dominate the neighbouring foothills (Box et al., 2000). As a result of centuries-long deforestation and drainage activities, most of the natural vegetation along the coast, rivers and foothills has been replaced by open grassland and farmland (de Klerk et al., 2009). Thus, an extensive system of drainage ditches and ridge-and-furrow fields forms a significant part of the recent relief on the Colchian plain (Nikolaishvili et al., 2015). This holds especially true for the slightly elevated Supsa fan where drier conditions exist in contrast to the swampier surroundings.

\subsection{Human occupation}

Georgia has been populated since the Palaeolithic; bones discovered at the site of Dmanisi are presently the oldest hominid remains outside of Africa (Lordkipanidze et al., 2007). During the Holocene, an early transition from hunting and gathering to farming and animal husbandry set in between 10000 and 9000 BCE (Arslanov et al., 2007). People spread from the foothills into the plain where the oldest settlement sites of Ontsakoshia (Janelidze and Tatashidze, 2010) and Ispani (Connor et al., 2007; de Klerk et al., 2009) date back to the transition between the Chalcolithic and the early Bronze Age in the mid-third millennium BCE. Since the early Bronze Age settlement mounds in the northern part of the Colchis have yielded evidence for the evolving Colchian culture (Lordkipanidze, 1991; Sens, 2009; Laermanns et al., $2017 \mathrm{~b}$ ). The region experienced its heyday between the sixth and fourth centuries BCE under the Kingdom of Colchis - a time of intensive trade contact with (mainly Milesian) Greek merchants, who had founded several colonies along the Colchian Black Sea coast (Sens, 2009; Gamkrelidze, 2012). In the late second to early first century BCE, Colchis fell into the sphere of influence of the Kingdom of Pontus. Later it became a client state of the Roman Empire (Gamkrelidze, 2012) and finally a Roman province (Rayfield, 2013).

Our knowledge of ancient Colchis is to some extent based on ancient Greek and Roman writers. One of the oldest accounts is the mythical journey of Jason and the Argonauts, a small band of heroes named after their ship Argo, who embarked for the Kingdom of Colchis on their quest to find the "Golden Fleece". Described in Homer's Odyssey (eighth-seventh century BCE), as background of Euripides' play Medea (fifth century BCE) and as subject of the epic

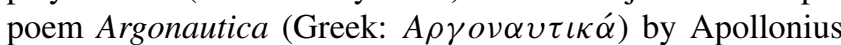
Rhodius (third century BCE), this myth is one of the most important narratives of Antiquity (Okrostsvaridze et al., 2016). Besides its adventurous story of Jason and his comrades, the saga reflects the impressions of Mycenaean Greeks from their first voyages to the Colchis in the late second millennium BCE (Okrostsvaridze et al., 2016). In the literature, opinions differ as to whether the Golden Fleece represents sheep skins which were used for the extraction of placer gold, as described by Strabo (Book XIII), Pliny the Elder and Appian of Alexandria, who all praise the gold and silver richness of the Colchian rivers (Okrostsvaridze et al., 2016), or if it symbolizes the wealth of Colchis in general (Braund, 1994).

\subsection{Research area}

Our investigations focus on the Supsa delta region and its adjacent areas, i.e. on the southernmost part of the Colchian plain (Fig. 1). Here, the Supsa River leaves the foothills and forms its lobe-shaped alluvial fan. The eponymous village covers the central part of the fan, while its surroundings are dominated by farmland (Fig. 3b). The prevailing ridge-and-furrow fields, which are divided by an extensive network of drainage channels, have overprinted the natural fluvial structures (cf. Fig. 2). Only in few swampy grassland areas have near-natural conditions prevailed. The recent river mouth is located ca. $6.5 \mathrm{~km}$ west of the fan apex. The graded shoreline is formed by a straight beach with several beach ridges behind, and it is strongly influenced by the northbound long-shore current (Korotaev et al., 2003). North of the river mouth, the villages Maltakva and Grigoleti stretch atop the linear structure of the coast-parallel beach ridges. The coast section is separated from the alluvial fan by swamplands and peat bogs which extend to the southern shores of Lake Paliastomi (Figs. 2, 3a). On the southern side of the river mouth, the foothills reach close to the graded shoreline.

Within this area several archaeological sites are known. Whole amphorae and fragments from Heraclea Pontica and Sinope were unearthed between the village Maltakva and the Supsa river mouth (Figs. 1, 2); they date to the fourth and third centuries BCE (Sadzradze et al., 1999). At the villages of Ureki and Maltakva, several Colchian amphorae (second and first centuries BCE) were found (Miron and Orthmann, 1995; Gamkrelidze, 2012). Some historians (e.g. Shafranov, 1880, in Gamkrelidze, 2012) even speculate that the ancient city of Phasis was located on the southern shore of Lake Paliastomi at the river mouth of the Supsa. Further upstream, many smelting furnaces were discovered through different surveys (Khakhutaishvili, 2008, 2009; Erb-Satullo et al., 2014). Their spatial concentration can be explained by the occurrence of chalcopyrite, the dominant copper-bearing mineral in quartz veins or iron oxide matrices (Gugushvili 


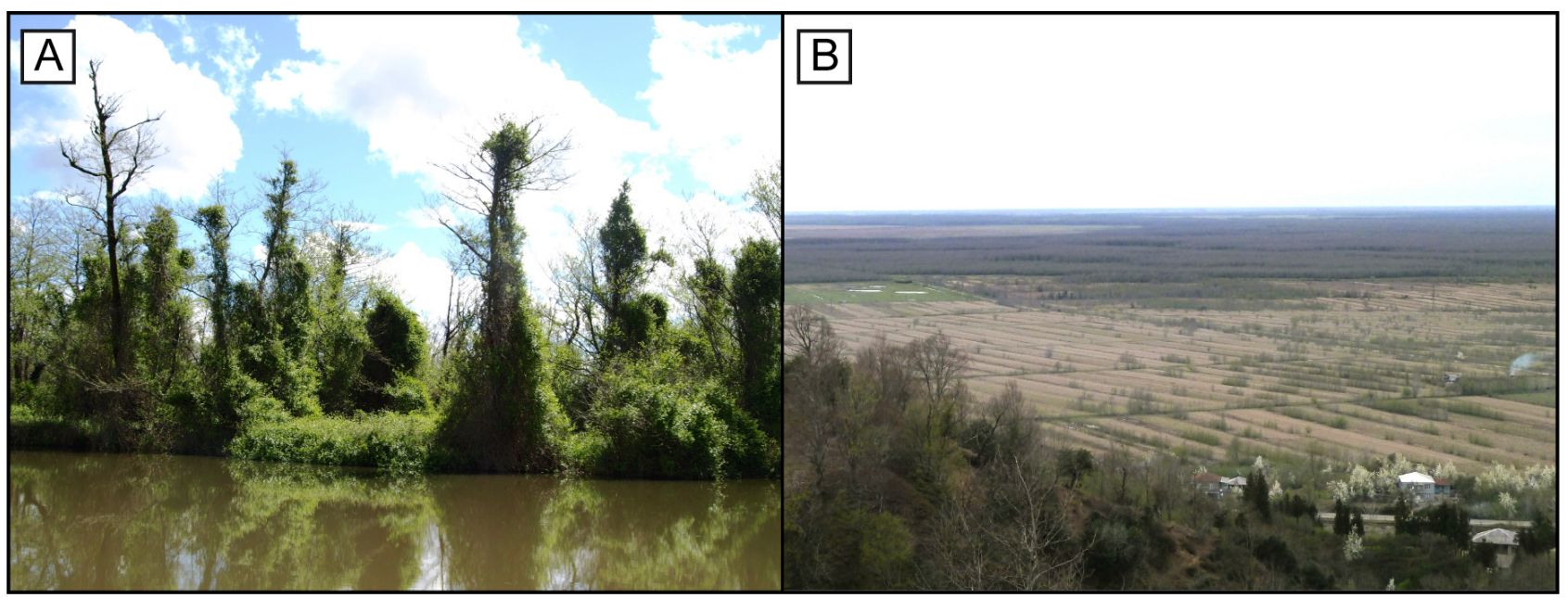

Figure 3. (a) Natural swamp forest vegetation close to the site of sediment core PIC 2 on the banks of the Pichora River. (b) Northward view from the foothills to the south of the village of Supsa. The ridge-and-furrow system of the agrarian areas is contrasted by the swamplands in the background (photos: Hannes Laermanns, 2014, 2015).

et al., 2010; Erb-Satullo et al., 2014). Chalcopyrite outcrops due to tectonic faults and erosion at the Adjara-Trialeti Thrust Belt (Okrostsvaridze et al., 2016).

\section{Methods}

\subsection{Geochemical and sedimentological analyses}

The coring sites of the delta area were chosen due to their accessibility and relevance. The sediment cores were retrieved using a Cobra TT (Atlas Copco) percussion-coring device. Only sediment core PIC 2 was taken further north, at the riverside of the Pichori, which discharges into Lake Paliastomi (Figs. 1,2). The diameter of the drill heads were 6 and $5 \mathrm{~cm}$, respectively, and coring reached a maximum depth of $12 \mathrm{~m}$ below surface (b.s.). These sediment cores form the basis for further stratigraphic and geochemical analyses and interpretations. Core description in the field encompassed sediment texture, colour and $\mathrm{CaCO}_{3}$ test (with $\mathrm{HCl}, 10 \%$ ) of the different sediment units. Samples were taken with intervals of ca. $20 \mathrm{~cm}$ for further treatment in the laboratory.

All analyses were conducted in the laboratory of the Institute of Geography, University of Cologne, Germany. The samples were oven-dried at $40^{\circ} \mathrm{C}$ for $48 \mathrm{~h}$, subsequently sieved $<2 \mathrm{~mm}$ and gently crushed with a mortar to disintegrate the aggregates.

For granulometric analyses, the samples were pre-treated with hydrogen peroxide $\left(\mathrm{H}_{2} \mathrm{O}_{2}, 15 \%\right)$ to remove organic matter and with sodium pyrophosphate $\left(\mathrm{Na}_{4} \mathrm{P}_{2} \mathrm{O}_{7}, 46 \mathrm{gL}^{-1}\right)$ to avoid coagulation. Before measurement, the samples were shaken for at least $12 \mathrm{~h}$ in an overhead shaker. Granulometric analyses were performed in 116 channels from 0.04 to $2000 \mu \mathrm{m}$ with a Laser Diffraction Particle Size Analyzer (LS 13320 Beckmann Coulter ${ }^{\mathrm{TM}}$ ), where each sample was measured three times using the optical Fraunhofer model. Grain-size parameters based on Folk and Ward (1957) were calculated using the GRADISTAT software version v8 (Blott and Pye, 2001). All grain-size categories are given according to the norm based on AG Boden (2005).

After separating the $<63 \mu \mathrm{m}$ fraction by sieving, the grain shape of samples from the sandy beds was analysed using a Retsch CAMSIZER ${ }^{\circledR} \mathrm{P} 4$. This fraction was measured in 52 channels up to $22.4 \mathrm{~mm}$ to define roundness, sphericity and elongation using the principle of dynamic image analysis (ISO 13322-2) to identify different deposition modes and possible sources. The results were calculated using the software CAMSIZER ${ }^{\circledR}$ 4.4.1.

Loss on ignition (LOI) was measured to estimate the organic matter content of the sediments. A total of $5 \mathrm{~g}$ of sample material were oven-dried at $105^{\circ} \mathrm{C}$ for $12 \mathrm{~h}$, and subsequently ignition was determined in a muffle furnace (Carbolite ELF) at $550{ }^{\circ} \mathrm{C}$ for $5 \mathrm{~h}$. Although possible uncertainties may result from the combustion of clay minerals, sulfates and/or carbonates, LOI is often used to estimate the organic matter content (e.g. Barsch et al., 2000; Heiri et al., 2001).

Element concentrations ( $\mathrm{Ca}, \mathrm{Al}, \mathrm{Fe}, \mathrm{K}, \mathrm{S}, \mathrm{Cu}, \mathrm{Zn}$ and $\mathrm{Pb}$ ) were measured by a portable XRF Analyzer (NITON XL3t, Thermo Scientific, analyticon) to draw conclusions on the depositional environment (marine or terrestrial origin) and on human influence (Oonk et al., 2009; Dung et al., 2013; Dirix et al., 2015). Triplicate measurements were performed on pellets of dried and ground sample aliquots, which were pressed into a Teflon ring with $12 \mathrm{Nmm}^{-2}$ and subsequently covered with a $4 \mu \mathrm{m}$ polypropylene film (X-ray film, TF240-255). A gold anode emitted X-ray (70 kV) needed to perform measurements within the "mining-minerals-mode", which uses four different filters for $40 \mathrm{~s}$ each. The secondary $\mathrm{X}$-rays of element-specific wavelength are detected and pro- 
cessed by a digital signal processor. Si concentrations (in $\mathrm{ppm})$ are calculated from the element-specific fluorescence energies and compared with external and internal reference materials (STDS-4, BCR142R, BCR-CRM 277). Magnetic susceptibility (MagSus) measurements were performed three times for each sample using a Bartington MS2B sensor.

Principal component analyses (PCAs) were applied using the software PAST (version 3.1.1, Hammer et al., 2001) to establish a statistically validated distinction of the different depositional facies (e.g. Zhang et al., 2002; Borůvka et al., 2005; Zhang and Mischke, 2009; Laermanns et al., 2017a). Therefore, standardized values of the granulometric parameters (mean grain size, sorting, kurtosis and skewness) were used to differentiate between the depositional modes (Folk and Ward, 1957). Additionally, a selection of the measured geochemical parameters, $\mathrm{Ca}, \mathrm{K}, \mathrm{Fe}$ and $\mathrm{Cu}$, that provided information about the origin of the sediments and, in the case of $\mathrm{Cu}$, possible human activity were standardized and added to the PCA (Oonk et al., 2009; Dung et al., 2013; Dirix et al., 2015). An additional PCA was applied for the sandy layers to differentiate their origins. The distribution of the data was explained by the first two components of each PCA.

\subsection{Dating techniques}

A total of 12 samples (plant remains and charcoal) from the three sediment cores SUP 3, 4 and 10 were taken for radiocarbon dating (Table 1) at the ${ }^{14} \mathrm{CHRONO}$ Centre, Queens University Belfast, Northern Ireland, UK. All ages were calibrated using Calib 7.1 (calibration data set: intcal13.14c; Stuiver and Reimer, 1993; Reimer et al., 2013). An age-depth model was calculated for the sediment core SUP 4 using the R-based software Bacon 2.2 (Blaauw and Christen, 2011).

\section{Results}

\subsection{Sediment cores}

\subsubsection{SUP 3}

SUP 3 was cored in the northern part of the Supsa fan (Figs. 2, 4, 5). The lowermost section (11.00-10.16 m b.s.) is composed of brown to dark brown silty to sandy peat. The layer is characterized by a heterogeneous grain-size composition, poor sorting and low values for all of the measured parameters. Between 10.16 and $8.75 \mathrm{mb}$ b.s., (dark) brownish grey clayey silt occurs with a more homogeneous grain size $(<7 \mu \mathrm{m})$. The layer of fine to medium sand at 8.75 $6.33 \mathrm{~m}$ b.s. is characterized by sharp boundaries, also indicated by the sudden rise in the mean grain size with values of $>100 \mu \mathrm{m}$ and elevated values of $\mathrm{Ca}, \mathrm{K}$, magnetic susceptibility (MagSus), $\mathrm{Ca} / \mathrm{K}$ and $\mathrm{Ca} / \mathrm{Fe}$ ratios. In contrast, the $\mathrm{S}$ content remains low. From $6.33 \mathrm{mb}$ b. to the surface, greyish brown to grey silts dominate with changing sand and clay contents and low values of LOI, MagSus, $\mathrm{Ca} / \mathrm{K}$ and $\mathrm{Ca} / \mathrm{Fe}$. Only between 4.53 and $4.00 \mathrm{~m}$ b.s., two layers of peat and sand are interdigitated, each $\sim 25 \mathrm{~cm}$ thick and confined by sharp boundaries. While the peat shows high LOI values (up to $\sim 47 \%$ ), the sand is characterized by a sharp peak in its $\mathrm{Ca} / \mathrm{Fe}$ ratio.

\subsubsection{SUP 9}

The sediment core SUP 9 was taken $150 \mathrm{~m}$ south of the SUP 3 site (Fig. 2). The lowermost part (10-9.55 m b.s.) consists of organic-rich (brownish) clayey silt. Then follows heterogeneous grey silt to silty sand. From 7.13 to $3.41 \mathrm{~m}$ b.s., homogeneous (brownish) grey clayey silts dominate once again; the mean grain size does not exceed $10 \mu \mathrm{m}$. Only an intercalation of brownish silt between 5.75 and $5.33 \mathrm{~m}$ b.s. stands out with coarser grain size and different colour. At $3.41 \mathrm{~m}$ b.s., an abrupt disconformity occurs with a shift to a $2 \mathrm{~m}$ thick heterogeneous brownish grey to grey fine to medium sand. The main grain size slightly decreases towards the upper facies limit at $1.41 \mathrm{~m}$ b.s., where brown sandy silt was deposited. The uppermost part $(0.72-0 \mathrm{~m}$ b.s. $)$ is formed of brown to reddish brown loamy silt.

\subsubsection{SUP 4}

SUP 4 was cored at the western margin of the Supsa fan (Figs. 2, 6). The basal part consists of (brownish) grey silty fine sand with very poor sorting, low MagSus and relatively low $\mathrm{Ca} / \mathrm{Fe}$ and $\mathrm{Ca} / \mathrm{K}$ ratios but high LOI values. This layer gradually merges into the subsequent peat, which stands out with high $\mathrm{Ca} / \mathrm{Fe}$ and $\mathrm{Ca} / \mathrm{K}$ ratios and low MagSus values. Above a sharp boundary, well-sorted clayey silt shows high concentrations of $\mathrm{Pb}, \mathrm{Zn}$ and $\mathrm{P}$ as well as low values of $\mathrm{S}$. At 9.46-9.23 m b.s. another peat occurs, which differs from the lower peat in terms of smaller matrix grain size, better sorting and very high $\mathrm{S}$ values. While its lower boundary is hard to define due to the gradual transition from the silt below, the upper boundary is rather sharp. Between 9.23 and $2.31 \mathrm{~m}$ b.s. grey silt occurs. The lowermost $(9.23-7.53 \mathrm{~m}$ b.s.) and uppermost (4.62-2.31 m b.s.) parts of this unit are characterized by relatively low $\mathrm{Ca} / \mathrm{K}$ and $\mathrm{Ca} / \mathrm{Fe}$ ratios, while $\mathrm{S}, \mathrm{Pb}$ and $\mathrm{Zn}$ reach very high levels. By contrast, the inbetween section (7.53 and $4.62 \mathrm{mb}$.s.) shows higher sand content, poorer sorting, elevated $\mathrm{Ca} / \mathrm{K}$ and $\mathrm{Ca} / \mathrm{Fe}$ ratios, as well as a high MagSus. After a disconformity follows silty sand with elevated values of $\mathrm{Ca} / \mathrm{K}, \mathrm{Ca} / \mathrm{Fe}$ and MagSus. The uppermost part of the core (1.88-0 m b.s.) is silty loam with a similar geochemical composition as the sand below.

\subsubsection{SUP 10}

Northwest of SUP 4, SUP 10 was cored beyond the western margin of the alluvial fan of the Supsa (Figs. 2, 7). The stratigraphy is dominated by fine to medium sand with interdigitated peats. From the maximum depth at 12 to $10.46 \mathrm{~m}$ b.s. (dark) grey fine sand shows high $\mathrm{Ca} / \mathrm{Fe}$ and $\mathrm{Ca} / \mathrm{K}$ ratios. After a disconformity follows a sequence of 
Table 1. Radiocarbon data set. Measurements were carried out at the ${ }^{14} \mathrm{CHRONO}$ Centre, Queens University Belfast, Northern Ireland, UK. All ages are calibrated using Calib 7.1 (calibration data set: IntCal13.14c; Stuiver and Reimer, 1993; Reimer et al., 2013) and are presented with $2 \sigma$.

\begin{tabular}{llrrlrl}
\hline Sample ID & Lab code & $\begin{array}{r}\text { Depth below } \\
\text { surface }(\mathrm{m})\end{array}$ & $\begin{array}{r}\delta^{13} \mathrm{C} \\
(\%)\end{array}$ & Material & $\begin{array}{r}\text { Conventional } \\
{ }^{14} \mathrm{C} \text { age BP }\end{array}$ & $\begin{array}{l}\text { Calibrated }{ }^{14} \mathrm{C} \text { age } \\
\text { (cal BCE/CE), 2 } \sigma\end{array}$ \\
\hline SUP 3/14 & UBA-34221 & 4.32 & -30.5 & Wood & $2180 \pm 27$ & $359-171$ BCE \\
SUP 3/22 & UBA-34222 & 6.40 & -28.5 & Wood & $3818 \pm 30$ & $2434-2143$ BCE \\
SUP 3/34 & UBA-34223 & 10.50 & -26.1 & Wood & $4423 \pm 58$ & $3336-2913$ BCE \\
SUP 4/6 & UBA-26767 & 1.35 & -28.3 & Plant fragment & $854 \pm 28$ & $1053-1257$ CE \\
SUP 4/11 & UBA-26768 & 2.35 & -21.0 & Wood & $1214 \pm 34$ & $690-891$ CE \\
SUP 4/19 & UBA-26769 & 4.70 & -30.9 & Wood & $2281 \pm 37$ & $404-209$ BCE \\
SUP 4/23 & UBA-26770 & 5.70 & -24.7 & Wood & $2404 \pm 39$ & $749-396$ BCE \\
SUP 4/36 & UBA-26771 & 9.27 & -26.3 & Wood & $4699 \pm 42$ & $3631-3370$ BCE \\
SUP 4/39 & UBA-26772 & 9.75 & -27.6 & Wood & $5111 \pm 74$ & $4045-3711$ BCE \\
SUP 4/41 & UBA-26773 & 10.50 & -24.9 & Wood & $4983 \pm 38$ & $3795-3660$ BCE \\
SUP 10/23 & UBA-34224 & 6.72 & -26.4 & Wood & $1126 \pm 27$ & $778-990$ CE \\
SUP 10/29 & UBA-34225 & 7.52 & -25.7 & Wood & $3492 \pm 29$ & $1893-1701$ BCE \\
\hline
\end{tabular}

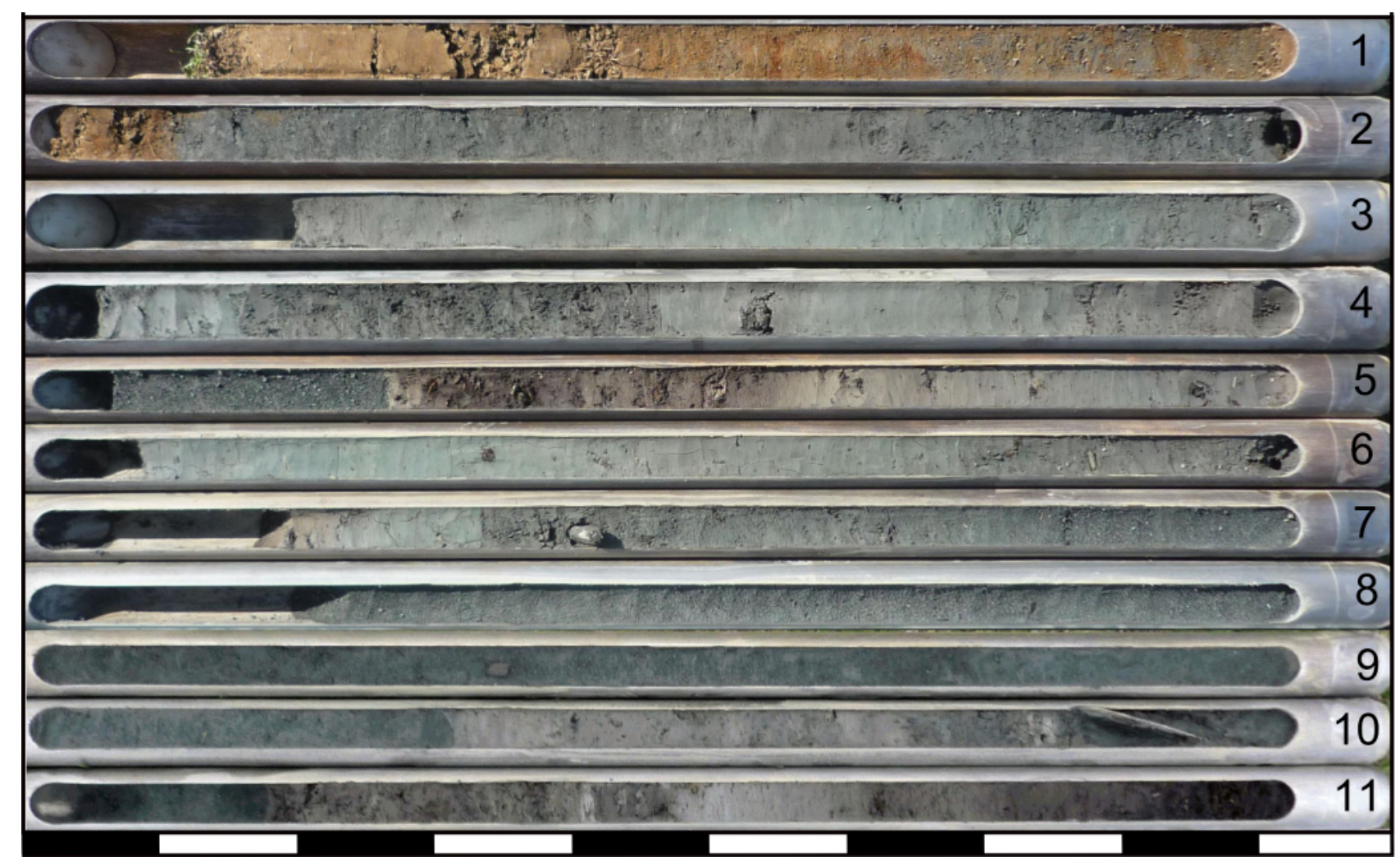

Figure 4. Sediment core SUP 3 from the maximum depth at $11 \mathrm{~m}$ b.s. (bottom right) to the surface (top left). Outer diameter of auger heads: $6 \mathrm{~cm}(0-4 \mathrm{~m})$ and $5 \mathrm{~cm}(4-11 \mathrm{~m})$ (photo: Hannes Laermanns, 2013).

several peat and organic-rich greyish brown strata with low $\mathrm{Ca} / \mathrm{Fe}$ and $\mathrm{Ca} / \mathrm{K}$ ratios, while LOI rises up to $>20 \%$. In general, this sequence is characterized by heterogeneous but generally low values of $\mathrm{Fe}, \mathrm{Cu}, \mathrm{Zn}, \mathrm{Pb}$ and $\mathrm{Ca}$. At 7.91$7.51 \mathrm{~m}$ b.s., massive wood occurs. Between 7.51 and $6.56 \mathrm{~m}$, the brownish grey silt contains many ceramic fragments, up to $2 \mathrm{~cm}$ long. In this unit $\mathrm{Ca} / \mathrm{Fe}$ and $\mathrm{Ca} / \mathrm{K}$ reach their minimum values, while $\mathrm{Fe}, \mathrm{Al}, \mathrm{Pb}, \mathrm{Zn}$ and $\mathrm{Cu}$ rise significantly. Then grey medium sand follows with a changing mean grain size of 90 to $450 \mu \mathrm{m}$. The sand unit is characterized by sharp lower and upper boundaries, low LOI contents, as well as low $\mathrm{Ca} / \mathrm{K}$ and $\mathrm{Ca} / \mathrm{Fe}$ ratios. The upper $2 \mathrm{~m}$ consists of grey 


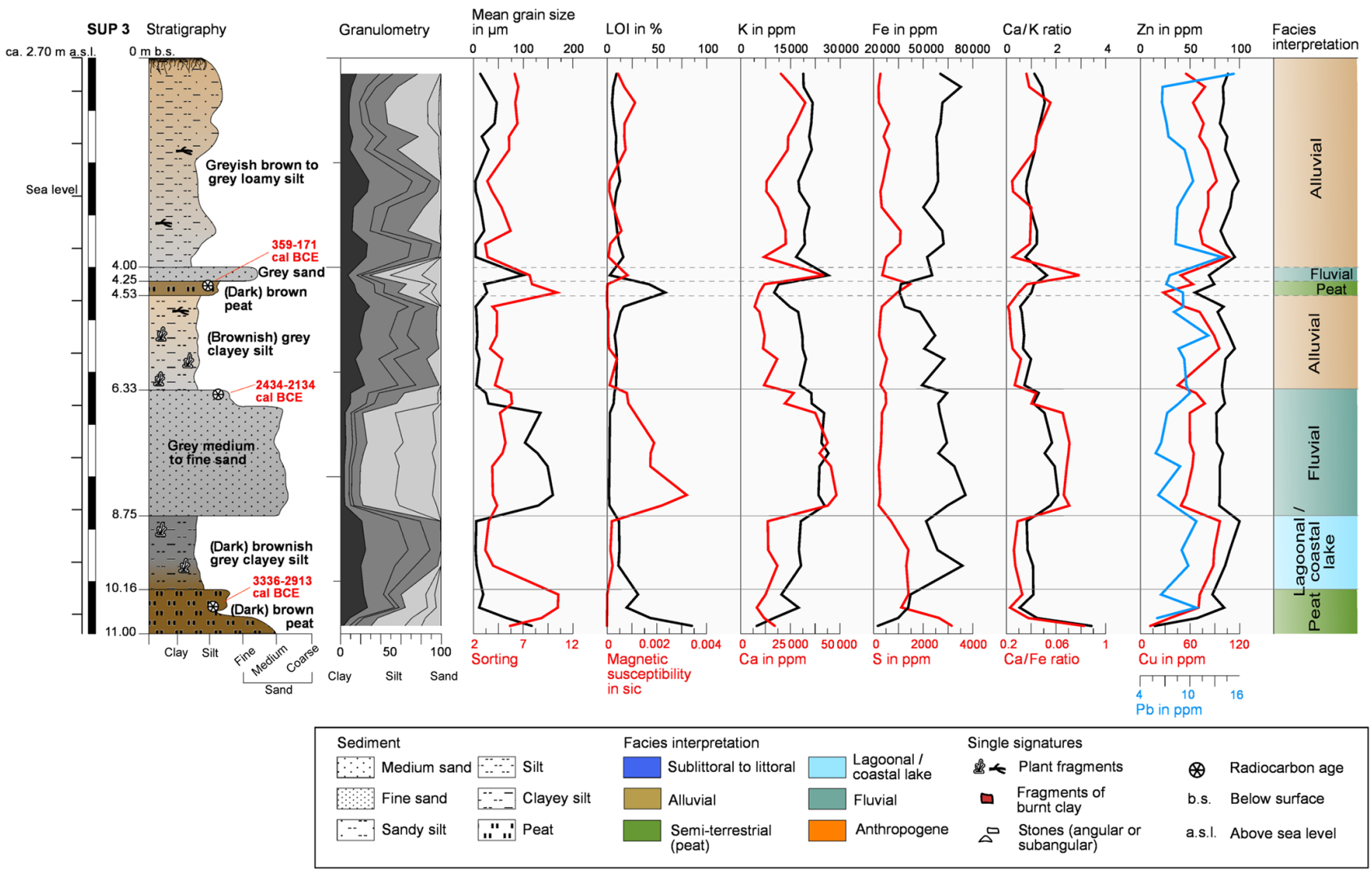

Figure 5. Profile, facies interpretation, granulometry, geochemistry and ${ }^{14} \mathrm{C}$ age estimates of sediment core SUP 3 from the northern part of the Supsa fan (location in Fig. 2). The sediment core is dominated by fine-grained alluvial layers, which are interdigitated with peats in the lower part of the fluvial deposits (see Fig. 3).
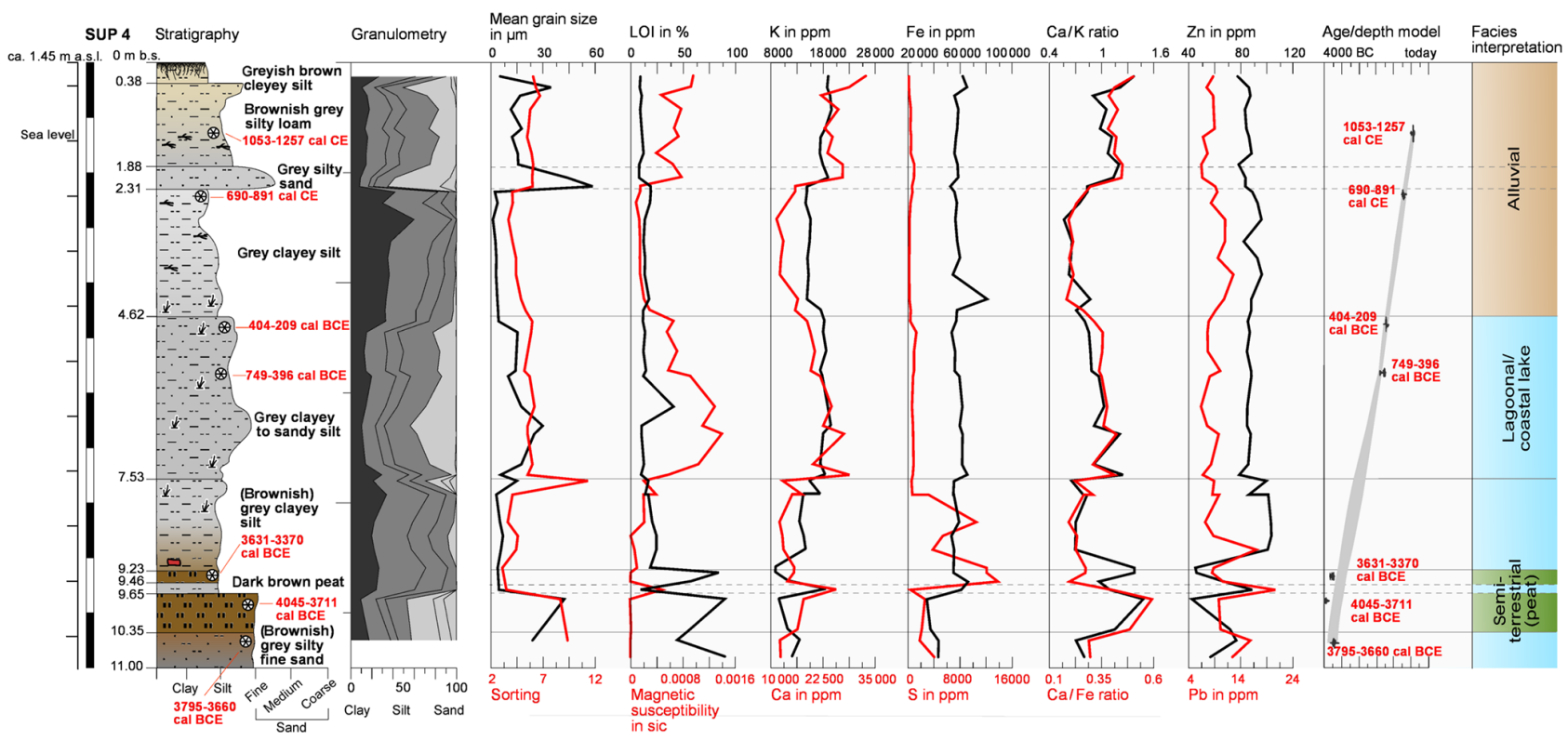

Figure 6. Profile, facies interpretation, granulometry, geochemistry and ${ }^{14} \mathrm{C}$ age estimates of sediment core SUP 4 from the western edge of the Supsa fan (for the legend, see Fig. 5). Except from the peat interdigitations below $9 \mathrm{~m}$ b.s., the entire sediment core consists of finegrained lagoonal to alluvial deposits, documenting the gradual change from a lagoon to a floodplain environment. The age-depth model was established with the R-based software Bacon 2.2 (Blaauw and Christen, 2011). 


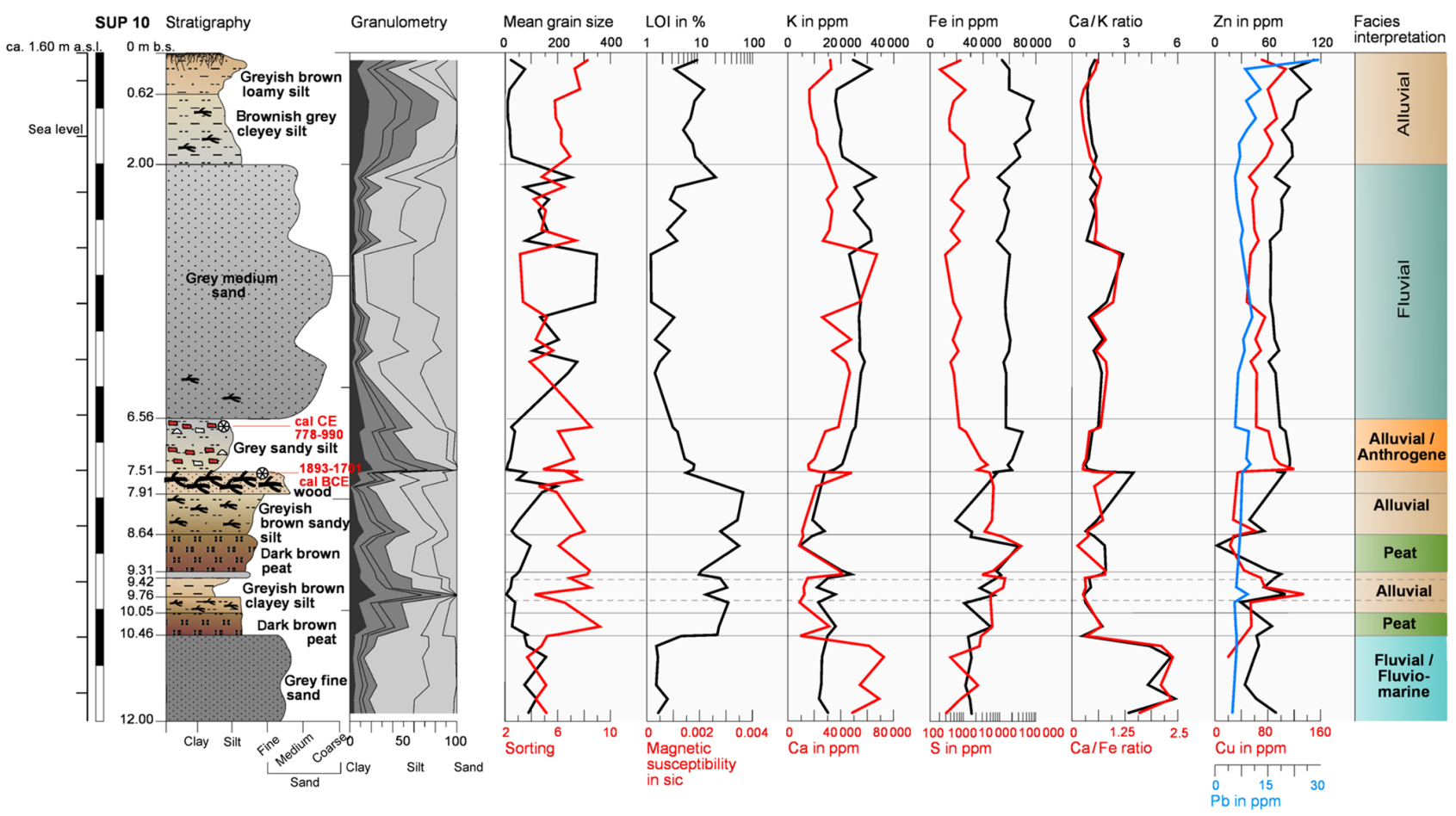

Figure 7. Profile, facies interpretation, granulometry, geochemistry and ${ }^{14} \mathrm{C}$ age estimates of sediment core SUP 10 from the area between the coast and the Supsa fan (see Fig. 2). Above fluvio-littoral deposits, peat is interdigitated with alluvial silts and topped by a layer with many ceramic finds at 7.51-6.56 m b.s. Then fluvial sand dominates until $2 \mathrm{~m}$ b.s. (for the legend, see Fig. 5).

to greyish brown loamy to clayey silt, in which $\mathrm{Zn}$ and $\mathrm{Pb}$ rise up to the surface.

\subsubsection{SUP 5}

Sediment core SUP 5, conducted on a grassland ca. $200 \mathrm{~m}$ north of the foothills (Fig. 2), is one of the two sediment cores taken on the southern riverside of the Supsa. The entire $10 \mathrm{~m}$ core consists of clayey to loamy silt. Its lowermost part contains several plant fragments. The sand content increases slightly between 8.31 and $4.56 \mathrm{mb}$.s. In the upper $2 \mathrm{~m}$, the grey to dark grey colour of the core changes to a greyish brown.

\subsubsection{SUP 6}

SUP 6, the second core taken from the southern side of the Supsa, originates from an outlet of a small tributary valley ca. $600 \mathrm{~m}$ southeast of the SUP 5 site (Fig. 2). In contrast to the fine-grain-dominated stratigraphy of SUP 5, SUP 6 contains several layers of medium sand (mean grain size varies between ca. 100 and $380 \mu \mathrm{m}$ ) from its maximum depth at 8 to $0.88 \mathrm{mb}$ b. The single sand layers can be divided by the occurrence of pebbles $(<3 \mathrm{~cm})$ at different depths. Above a small silt layer at 3.58-3.52 m b.s., the $\mathrm{Ca} / \mathrm{K}$ and $\mathrm{Ca} / \mathrm{Fe}$ ratios fall to lower levels, while the concentrations of $\mathrm{Zn}$ and $\mathrm{Cu}$ rise. The uppermost $0.88 \mathrm{~m}$ of the core consists of brown sandy loam with some pebbles and coarse plant fragments.

\subsubsection{SUP 7}

SUP 7, the westernmost sediment core, is from a grassland between the coast and the village of Ureki (Fig. 2). The lowermost part (5-1.91 mb.s.) consists of dark grey medium sand with a mean grain size between $\sim 140$ and $300 \mu \mathrm{m}$. Above, grey clayey silt was deposited between 1.91 and $1.16 \mathrm{~m}$ b.s. Homogeneous grey fine sand (mean grain size $\sim 50 \mu \mathrm{m}$ ) follows at $1.16-0.77 \mathrm{mb}$.s. The uppermost part is built up of (greyish) brown loamy silt.

\subsubsection{PIC 2}

PIC 2 was cored on the banks of the Pichora River (Figs. 2, 3a). Its lowermost part consists of dark grey to greyish brown medium sand. While $\mathrm{P}, \mathrm{Zn}$ and $\mathrm{S}$ remain at low levels, a marked decrease in $\mathrm{Ca}, \mathrm{Ca} / \mathrm{Fe}$ and $\mathrm{Ca} / \mathrm{K}$ values occurs within this layer. The subsequent stratum (2.93-1.26 m b.s.) of poorly sorted loamy silt is clearly separated from the previous and subsequent sand layers; it reveals slightly increased values of $\mathrm{Pb}, \mathrm{Zn}, \mathrm{P}$ and $\mathrm{S}$, while $\mathrm{Ca} / \mathrm{K}$ and $\mathrm{Ca} / \mathrm{Fe}$ ratios remain at low levels. The upper sand layer stands out with a mean grain size of up to $\sim 320 \mu \mathrm{m}$, comparable to the sand layer in the lower part of the core. Most of the geochemical values are close to the loam layer in between. The uppermost part is a humus-rich fine-grained deposit. 


\subsection{Radiocarbon dating results}

Altogether, 12 samples from the sediment cores SUP 3, SUP 4 and SUP 10 were ${ }^{14} \mathrm{C}$ AMS dated (see Figs. 5 to 7 , Table 1). The results are given with $2 \sigma$ confidence interval.

The seven age estimates from SUP 4 cover a time span of roughly 5000 years (3756 BCE to $1261 \mathrm{CE}$; mean ages). Though the $2 \sigma$ ranges of the two lowermost samples, SUP 4/39 and SUP 4/41, overlap, an age inversion cannot be excluded. The age estimates from SUP 3 cover $\sim 3000$ years and ca. $6 \mathrm{~m}$ of sediment. For SUP 10, only two samples were used for radiocarbon dating. They derive from the lower and upper facies limit of the archaeological layer at 7.51$6.56 \mathrm{~m}$ b.s., covering a time span between 1893-1701 BCE and $778-990 \mathrm{CE}$ ( 2480 to 2900 years).

\subsection{Statistical analyses of the sedimentological and geochemical data}

By means of a principal component analysis using granulometric parameters (mean grain size, sorting, kurtosis and skewness) and the geochemical parameters $\mathrm{Ca}, \mathrm{K}, \mathrm{Fe}$ and $\mathrm{Cu}$, the three main components were estimated as follows: PC 1: 41.4\%; PC 2: 24.9\%; and PC 3: $11.6 \%$ (Fig. 10a, b). The majority of samples in Fig. 10a cluster on the left side of the $y$ axis (quadrants I and III) and refer to high values of $\mathrm{Cu}, \mathrm{Fe}$ and skewness. They are considered to be of lagoonal or alluvial origin. The poor sorting and scattered distribution in quadrant III coincide with high values of loss on ignition (cf. Figs. 5-9), and, therefore, an enrichment of organic matter. In quadrant II, samples with high values of $\mathrm{Ca}$, mean grain size and (to a certain extent) $\mathrm{K}$ are considered to be of fluvial origin. Quadrant IV shows samples of the sediment core PIC 2 and the lower part of SUP 10. Between these two groups sandy samples that derive from SUP 7 are situated.

Further, a PCA (Fig. 10c, d) that focuses on the sandy sediments was calculated with 25 representative samples. Besides the factors used in the former model, the grain shape parameters of roundness (RNDS), sphericity (SPHR) and elongation (the length-width ratio $b / l$ ) (Kasper-Zugbillaga et al., 2005; Eamer et al., 2017) were included. Within this PCA, the first three axes explain $40.3 \%, 25.5 \%$ and $14.5 \%$, respectively. The outlier position of the samples of sediment core PIC 2 and the lower part of SUP 10 is confirmed, as well as the exception of the samples of SUP 7.

\section{Discussion}

\subsection{Facies determination}

Based on the granulometric, geochemical and statistical results, six different depositional facies units were defined.

- Facies A: sublittoral to littoral.

The majority of the relatively well-sorted medium sand of SUP 7 stands out with very coarse mean grain size up to $\sim 300 \mu \mathrm{m}$ and a unimodal grain-size distribution. This points to hydrodynamic conditions with rather high sediment transport capacities, consistent with wavedominated coastal conditions (Folk and Ward, 1957; Hesp, 2002; Dingler, 2005). The geochemistry is characterized by relatively high values of $\mathrm{Ca}$ and $\mathrm{K}$ and low values of Fe. In Fig. 10 A they scatter between the two outlier groups in quadrants II and IV. However, a separation from facies D remains challenging due to the proximity of the Supsa river mouth and its fluvial deposits. Nonetheless, the littoral deposits show a slightly better sorting.

- Facies B: alluvial (overbank deposits).

Although they are of riverine origin, similar to facies E, these deposits are listed separately due to their different characteristics and deposition modes. Facies B is characterized by silty to clayey sediments with elevated $\mathrm{K}$ and Ca contents and relatively low LOI values. It can be found in all of the analysed drill cores and dominates the stratigraphy of SUP 3, SUP 4 and SUP 6. It was deposited as a suspended sediment load across the floodplain surface by diffuse and channelized flows (Dunne and Aalto, 2013). These overbank fines are accumulated in slack waters of floodplain depressions (Blair and McPherson, 1994). In this facies, coarser layers with varying fine sand content and $\mathrm{Ca} / \mathrm{Fe}$ and $\mathrm{Ca} / \mathrm{K}$ values represent fluctuating hydrodynamic conditions during the outflow of fluvial deposits, e.g. during the formation of crevasse splays by breaching of levees of the Supsa (or Rioni) River (North and Davidson, 2012).

- Facies C: semi-terrestrial (peat and organic-rich deposits).

Facies $\mathrm{C}$ is characterized by poor sorting and considerably elevated LOI and $\mathrm{K}$ values. The numerous wellpreserved macroscopic plant remains and, to some extent, elevated $\mathrm{Fe}$ and $\mathrm{S}$ values point to anoxic conditions (Turney et al., 2005). The high TOC/N ratios (Joosten et al., 2003) indicate the dominance of cellulosic plants of peat bogs (Meyers and Teranes, 2001). Although there are many layers with high LOI values and plant fragments, real peat layers were only found in drill cores SUP 3, SUP 4 and SUP 10, where LOI rises above $30 \%-40 \%$ (AG Boden, 2005). 

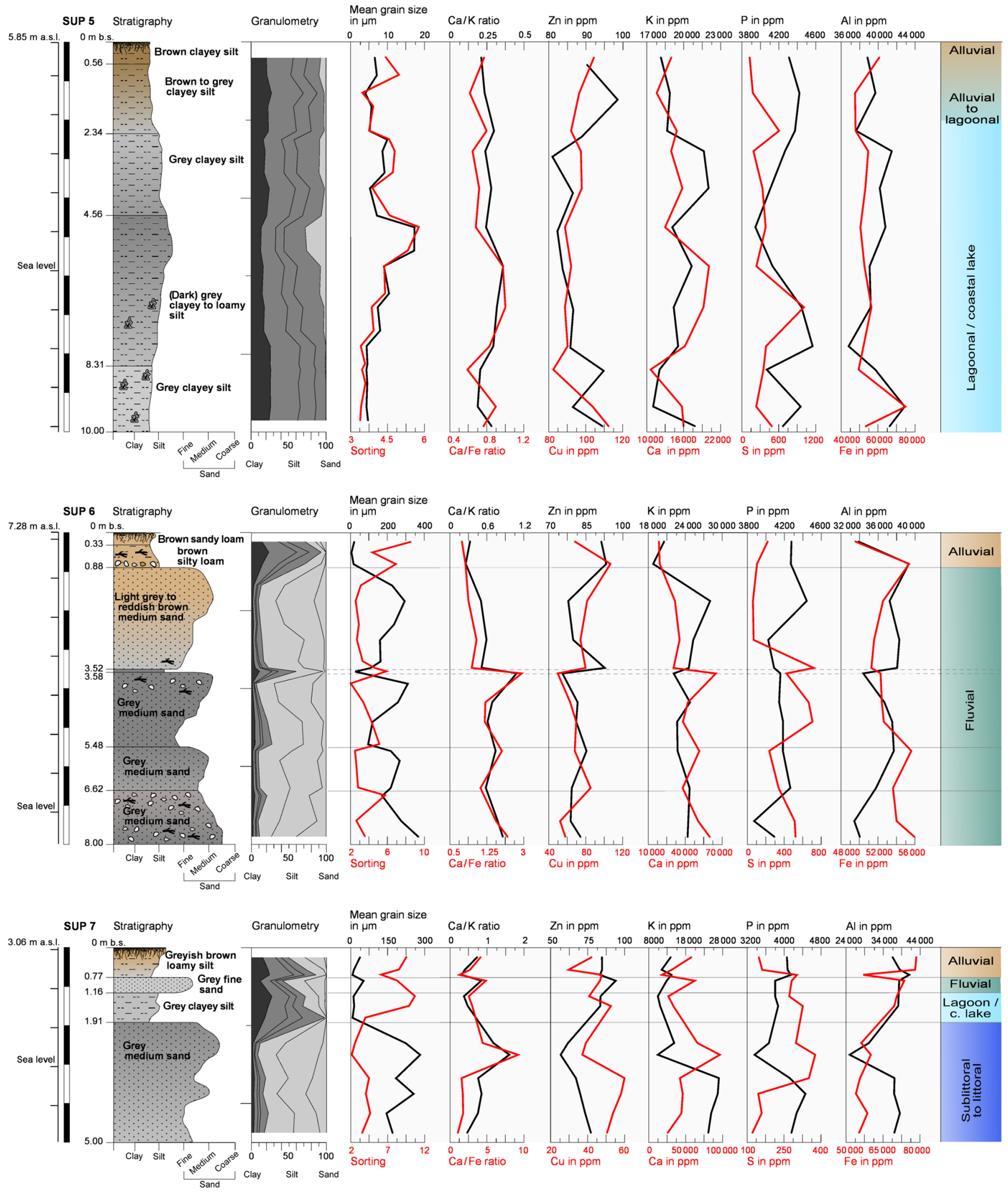

Figure 8. Profiles, facies interpretation, granulometry and geochemistry of the sediment cores SUP 5, SUP 6 and SUP 7. The former two are located at southern banks of the Supsa in the vicinity of a smaller tributary, the latter is located close to the coastline south of the recent river mouth (cf. Fig. 2). 


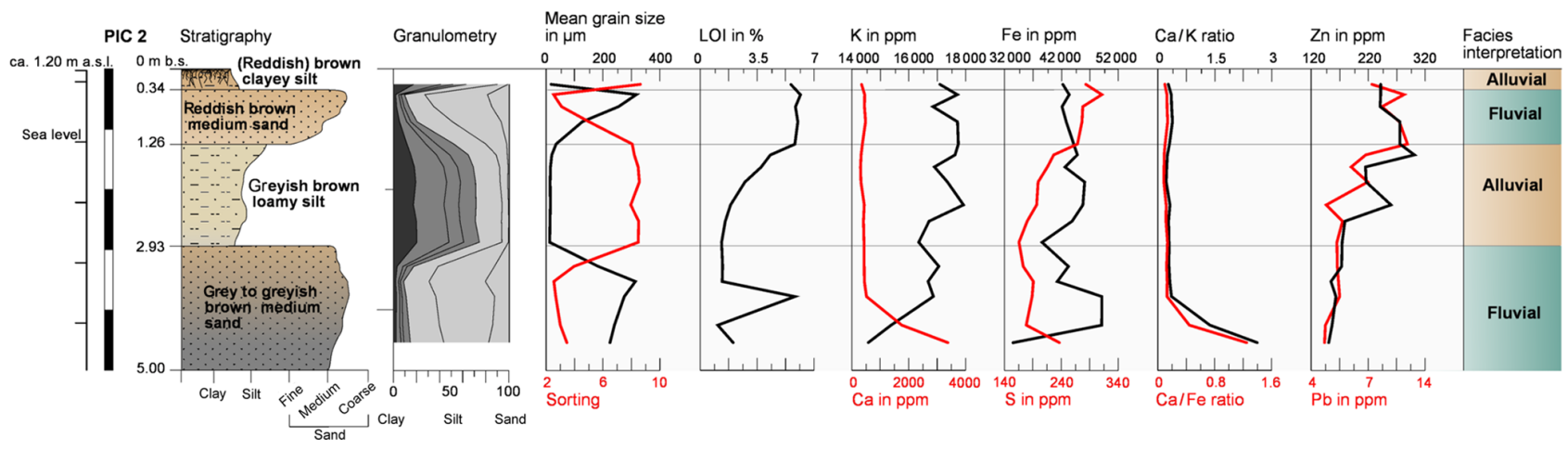

Figure 9. Profile, facies interpretation, granulometry, and geochemistry of sediment core PIC 2 from the banks of the Pichora River ca. $7 \mathrm{~km}$ north of the Supsa fan (Figs. 2, 3a). The sand-dominated core is strongly influenced by Pichora and Rioni deposits.

- Facies D: lagoonal or coastal lake.

In terms of grain size and geochemistry, the sediments of this facies closely resemble the sediments of Facies B. However, facies D stands out for slightly higher $\mathrm{Ca} / \mathrm{Fe}$ and $\mathrm{Ca} / \mathrm{K}$ ratios and lower $\mathrm{Si}$ and $\mathrm{Ti}$ contents (Cuven et al., 2011; Martin-Puertas et al., 2011). The strong resemblance to Facies B can be explained by the slow transition from a still water environment to deltaic semi-dry conditions. Since there is no microfaunal evidence, it remains challenging to estimate the salinity. Therefore, we cannot differentiate between a lagoon and coastal lake. Although deposited under low-energy conditions, several samples from the lagoonal or coastal lake strata reveal a coarser grain size. The granulometric variations may be explained by changing conditions within the water body, such as the floods from the landward side and storm surges or tsunamis from the seaward side.

- Facies E: fluvial.

A large portion of the sandy deposits in the sediment cores are characterized by moderate to poor sorting and slightly elevated $\mathrm{Fe}$ and $\mathrm{K}$ values, which hints at an increased input of terrestrial material (Arz et al., 1998; Kujau et al., 2010). They were found in sediment cores SUP 3, SUP 4, SUP 6, SUP 7, SUP 10 and PIC 2 and can be assumed to be of fluvial origin, primarily linked to sediment input by distributary channels of the Supsa. The varying grain size, for instance, can be explained by river avulsion and channel migration, as well as deposition during larger floods in areas close to distributary channels. Though there are some terrestrial markers (e.g. increased $\mathrm{Fe}$ and $\mathrm{K}$ values; cf. Davies et al., 2015), and, in general, this facies is quite heterogeneous (Dunne and Aalto, 2013), the differentiation from facies A remains challenging. The similar characteristics can be explained by the close proximity of the river mouth to the shoreline. Many littoral deposits derive from the Supsa, are only transported for a short distance along the shore and are then redeposited by the sea. By means of the lower values of roundness and sphericity (Fig. 10c), an approximate separation can be achieved (cf. Kasper-Zubillaga et al., 2005). The lowermost stratum of sediment core SUP 10 shows a slightly better sorting than most other layers of this facies. A certain marine or littoral influence may be assumed; this will be discussed in Sect. 5.3. Furthermore, facies E is differentiated from facies $B$, although both derive from the rivers and may also have the same origins. However, the fine-grained facies B is deposited as suspended sediment load across the floodplain surface (Dunne and Aalto, 2013), while facies E is limited to areas close to the stream currents where coarser sands are accumulated.

- Facies F: anthropogenic.

This facies occurs only in the sediment core SUP 10 between 6.56 and $7.51 \mathrm{mb}$.s. The fine-grained matrix closely resembles facies B. However, the large number of burnt clay, ceramic fragments and charcoal indicates a human-induced deposition or, at least, a strong postdepositional human influence. In the other cores, only random finds of burnt clay fragments and charcoal indicate a possible human activity.

\subsection{Implications for the local relative sea-level evolution}

As for reconstructing former sea levels, the most reliable samples of this research derive from peat layers, which are directly related to the back-barrier groundwater table and, thus, to the local relative sea level (Pirazzoli, 1996; Vött, 2007; Brückner et al., 2010; Laermanns et al., 2017a). Regarding the stratigraphical position of most peat layers - they are superimposed by lagoonal or coastal lake deposits - a peat growth in a situation comparable to the swamps and peat bogs of floodplains today and a subsequent drowning in the course of relative sea-level (RSL) rise seems most likely. Although the peat might also derive from riverine en- 


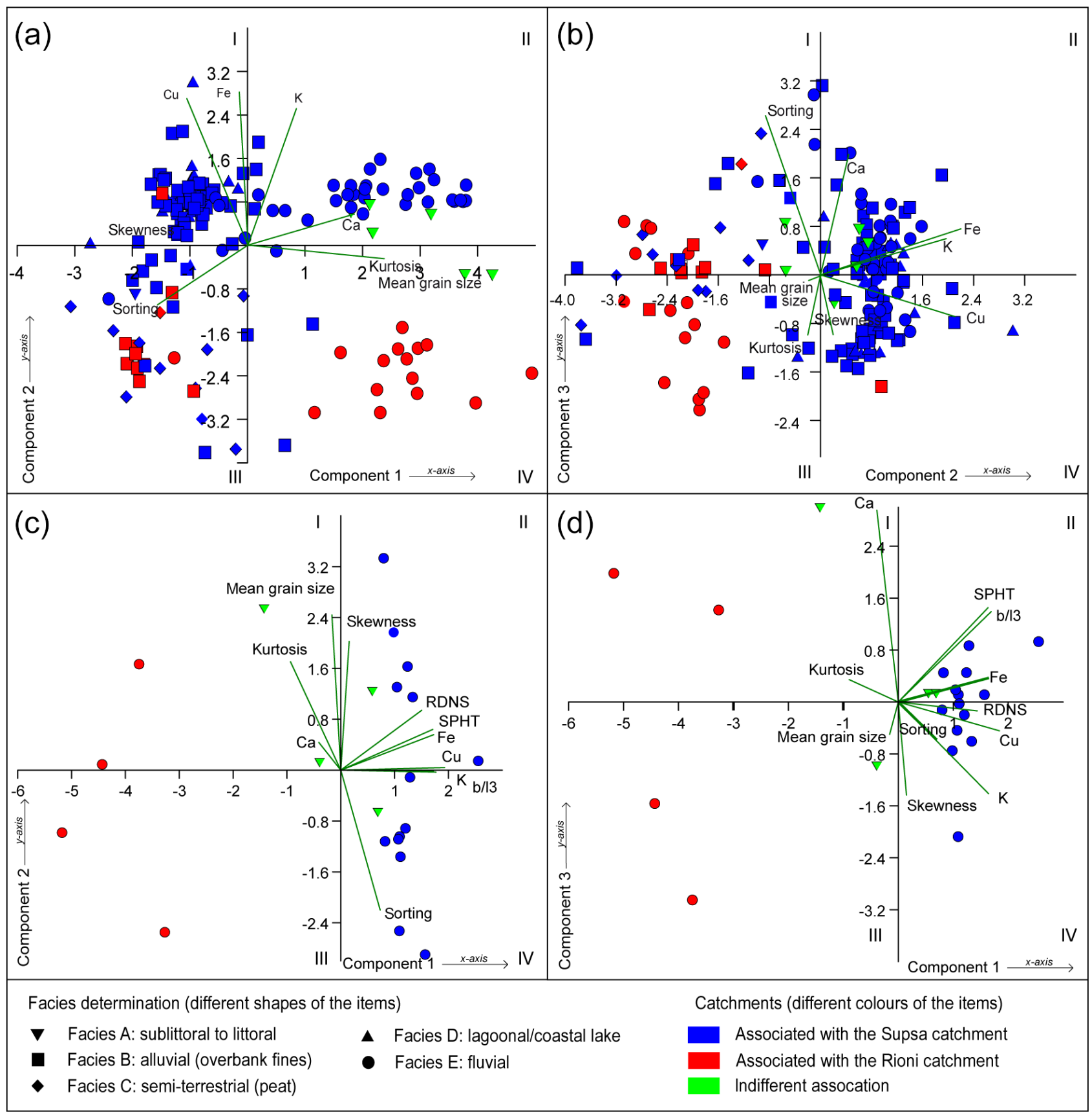

Figure 10. Principal component analyses (PCAs) to decipher the origins and depositional modes of the sediments. (a) PCA uses the geochemical parameters $\mathrm{Ca}, \mathrm{Fe}, \mathrm{K}$ and $\mathrm{Cu}$, as well as the granulometric parameters mean grain size, sorting, skewness and kurtosis (PC 1: 41.4\%; PC 2: 24.9\%; PC 3: 11.6\%). The axes represent components 1 and 2, while PCA B is based on the components 1 and 3. Panels (c) and (d) show PCAs on a selection of sandy samples using the parameters of PCA A plus the grain-shape parameters roundness (RNDS), sphericity (SPHR) and elongation $(b / l)(\mathrm{PC} 1: 40.3 \%$; PC 2: 25.5\%; PC 3: $14.5 \%)$, plotted on the components 1 and 2 (PCA C) and components 1 and 3 (PCA D).

vironments of the Supsa fan, such as oxbows, we assume a comparable groundwater table due to the proximity to coast and floodplain environments and, therefore, an indirect sealevel indicator even if marine layers were not reached. In any case, a vertical error range should be considered for
RSL reconstructions based on these peat layers, the extent of which is still debated. Only limited data exist to compare and quantify compaction (Törnquist et al., 2008). While Pirazzoli (1996) calculated a general vertical error bar of ca. $0.5 \mathrm{~m}$, recent publications instead hint to varying rates, 


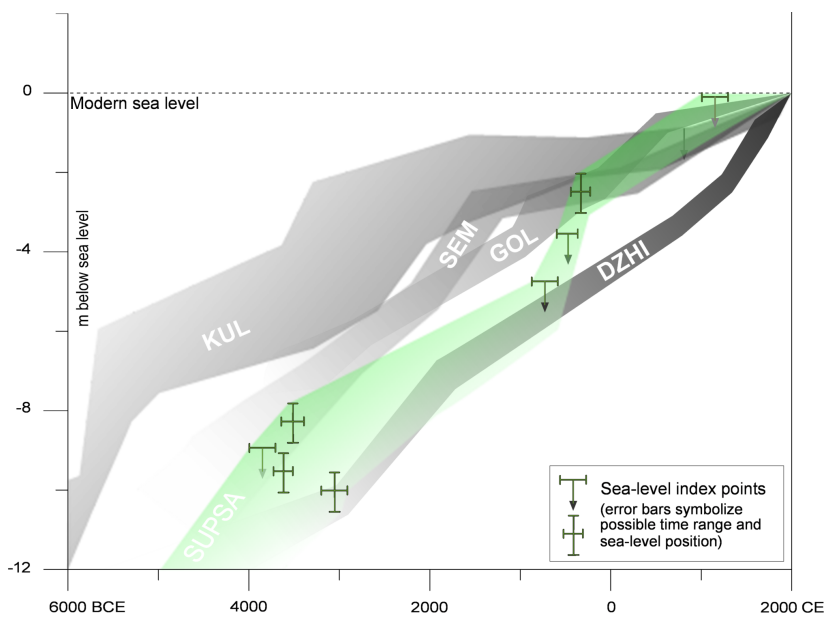

Figure 11. Sea-level index points based on radiocarbon dating of the Supsa delta region with the first estimated sea-level trend (SUPSA, in green). An arrow pointing downwards indicates ${ }^{14} \mathrm{C}$ dated material from an alluvial context; a cross indicates ${ }^{14} \mathrm{C}$-dated paralic peat. For comparison, sea-level curves from the central part of the Colchian plain (KUL) and from sites on the Taman Peninsula (southwestern Russia, northeastern Black Sea: SEM, GOL, DZHI) are also shown. KUL: Kulevi area north of Poti (Laermanns et al., 2017a); SEM: Semebratnee (Brückner et al., 2010); GOL: Golubitskaya (Kelterbaum et al. 2011) and DZHI: Dschiginka (Fouache et al., 2012).

depending on grain size distribution, organic matter and water content (Horton and Shennan, 2009). These factors affect not only the peat layers but also with varying influence the (fine-grained) Holocene sediments below (Bungenstock and Weerts, 2010). From such layers derive the samples that were taken from alluvial facies. These index points serve as indicators for the maximum sea-level position at a certain time. Besides compaction, other mechanisms, such as tectonic subsidence, must be taken into consideration (Bungenstock and Weerts, 2010). Therefore, the sea-level position for each data point can only be seen as a relative indicator (Fig. 11) and must not be transferred to other locations, where different sedimentary and tectonic settings may prevail (Bungenstock and Weerts, 2012).

Although establishing a relative sea-level curve for the Supsa area remains challenging due to the small number of radiocarbon-dated index points of the former sea levels, a local relative sea-level position at about -10 to $-8 \mathrm{~m}$ can be reconstructed for the time between 4000 and 3500 BCE. Later, during the first millennium BCE, a gradual but relatively steep rise from -5 to $-3 /-2 \mathrm{~m}$ is suggested. During the second millennium CE, the RSL approximates the modern level. We are aware that these ${ }^{14} \mathrm{C}$-dated sea-level indicators and the limited knowledge about tectonics, compaction and subsidence rates (Gamkrelidze, 1998; Adamia et al., 2011) include several uncertainties (Brückner et al., 2010). Furthermore, changes in the coastline, e.g. opening or closing of the lagoon (Lake Paliastomi) or dislocations of the palaeochannel of the Supsa, might have had a major influence on the samples' setting as well. However, the comparison with earlier studies of the region reveals at least similar trends. In general, the sea-level evolution in the Supsa area mirrors the investigations between the rivers Rioni and Khobistskali (Laermanns et al., 2017a). However, the steeper RSL rise from the fourth to the first millennium BCE presented there (Fig. 11) might be attributed to the different location closer to the Rioni and the resulting different compaction and subsidence.

There are several similarities between these RSL data from Georgia and those from the Taman Peninsula at the sites of Semebratnee (Brückner et al., 2010), Golubitskaya (Kelterbaum et al., 2011) and Dschiginka (Fouache et al., 2012). Especially when compared to the RSL curves of Semebratnee and Golubitskaya for the last $\sim 3000$ years, these curves look much like the one from the Supsa delta region. Before 2000 BCE, our RSL indicators fit well with the curves of Semebratnee and Dschiginka. In general, the RSL curve from the Colchian coast of Georgia resembles those of the Taman Peninsula and others of the Mediterranean quite well (Vött, 2007; Vött et al., 2007; Brückner et al., 2010). As already stated, the differences between the single curves most likely originate from local effects, such as different subsidence and compaction rates as well as local tectonics. It is in any case noteworthy that no hints for significant sea-level oscillations during the mid-Holocene to late Holocene, as proposed by various authors (especially Balabanov, 2007), were detected in our data.

\subsection{Palaeo-environmental evolution of the Supsa delta area}

The sediment record elucidated by the drilling from the Supsa area yields some hints for the landscape change that has taken place since the mid-Holocene. While being a contribution to the complex formation of the fan, the data from individual cores can only provide local information. However, several repetitive patterns were identified, so that the general process pattern can be revealed.

The sands in the lowermost part of sediment core SUP 10 closely resemble, in terms of geochemistry, sorting and grain shape parameters (Figs. 7, 9 and 11), those of sediment core PIC 2, suggesting a littoral relocation of deposits originating from the Rioni; this may explain their differentiation from the Supsa fan deposits. Due to their slightly better sorting and a possible relocation, they were considered not to be deposits of the alluvial fan sensu stricto and were classified as fluvio-marine deposits instead (Fig. 7). Considering the 25times higher sediment load of the Rioni today (Berkun et al., 2015), this seems quite likely. However, there is no evidence for a progradation of the Supsa fan to any of the investigated sites before 3000 BCE (Fig. 12a). Instead, the growth of paralic (coastal) peat continued, comparable to the Rioni area 

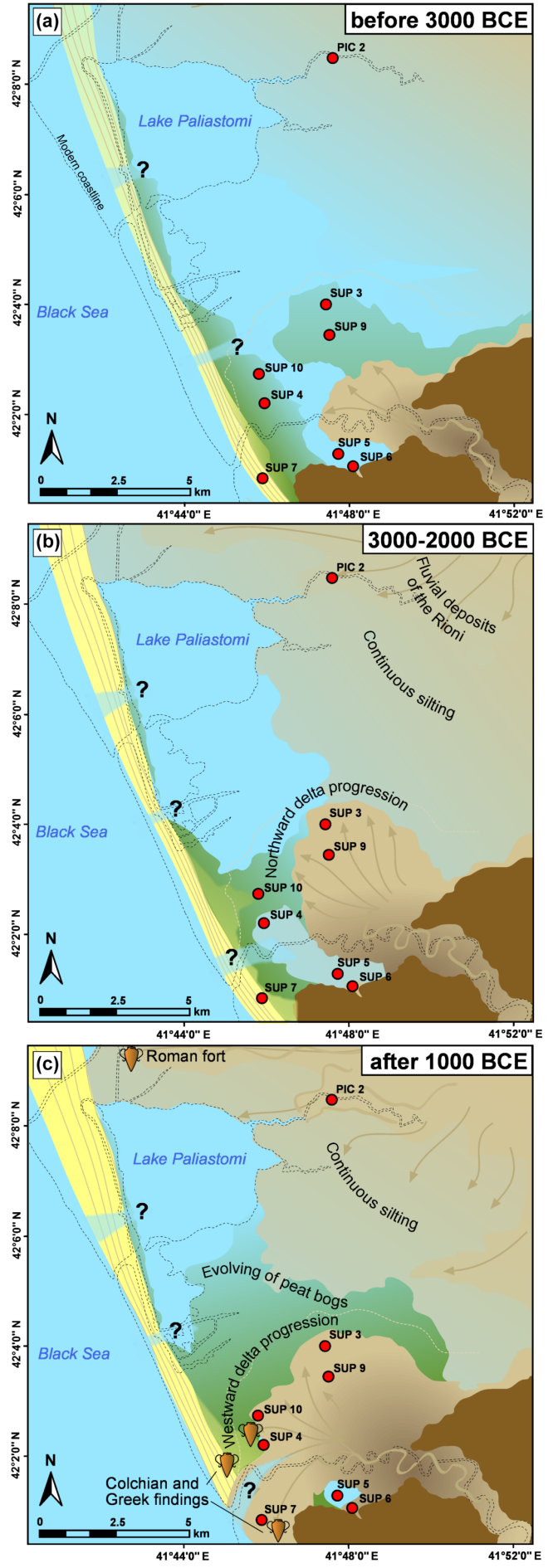

Figure 12. Palaeoenvironmental evolution of the Supsa delta region and adjacent areas. The transformation from lagoonal conditions (a) to an alluvial plain took place since at least $3000 \mathrm{BCE}$. The Supsa River built a remarkable fan that prograded first northwards (b) and later shifted westwards (c). During the first millennium BCE, Colchians and Greeks settled between the fan and the coastline which is documented by ceramic finds and graves, among other sources. further north (Laermanns et al., 2017a). This holds true for northern and western parts of the Supsa fan, where at the sites of the sediment cores SUP 3 and SUP 4 peat growth is indicated since the mid-fifth to the mid-fourth millennium BCE (Figs. 5, 6 and 12, Table 1). This indicates that at least since some time before $3000 \mathrm{BCE}$, a sand spit had evolved by the longshore drift, which separated the research area from the open sea. Since then, lagoonal conditions represented the continuation of the Holocene transgression (Ryan, 2007; Giosan et al., 2009; Fouache et al., 2012). When the growth of the paralic peat could not keep pace with the ongoing rise in sea level, it was covered by fine-grained sediments related either to standing water bodies, such as shallow lagoons or coastal lakes, or to alluvial deposits (for SUP 4, see Fig. 6).

In contrast to this general process, which can be assumed for the entire Colchian plain during the mid-Holocene, the evolution of the Supsa fan forms an outstanding element of the local geomorphology. While in the open plain finegrained material dominated the stratigraphy, the Supsa River introduced an exceptional share of coarser sediments on the plain, related to the formation of the semi-circular alluvial fan just north of the foothills of the Lesser Caucasus. Its natural shape is clearly visible and protrudes beyond the surrounding plain, although the intensive agricultural use and drainage systems have strongly reshaped the terrain.

Furthermore, the sandy sediment of the Supsa fan can be separated from sandy deposits of the Rioni-dominated floodplain sediments by higher $\mathrm{K}$ and Fe contents, a higher grade of sphericity and slightly poorer sorting (Fig. 10), which most likely derived from the different geologic settings and transport distances. The typical interdigitations of alluvial fan-related distributary channels and fine-grained alluvial deposits are reflected in sediment core SUP 3 and in the upper part of SUP 10. The chronostratigraphy of SUP 3 in the northern part of the fan indicates that channel deposits of $\sim 2.40 \mathrm{~m}$ thickness reached that site after the mid-third millennium BCE (Fig. 12b). Similar deposits were found in sediment cores SUP 4 and SUP 10 in the western section of the fan, although of different thickness and grain size; here, these channel deposits accumulated considerably later, i.e. in the first millennium CE (Fig. 12c). A comparable layer recurs in the northern sediment core SUP 3 as well, just above a peat layer, which dates to the second half of the first millennium BCE. These results indicate that the main activity and progradation of the Supsa fan shifted between the second millennium $\mathrm{BCE}$ and the first millennium $\mathrm{CE}$ from north to west.

Besides this general fan evolution several areas were only marginally affected by the progradation. Sediment core SUP 5, where only fine sediments were found, exemplifies that close to the foothills of the Lesser Caucasus the quiescent depositional conditions of the central Colchian plain have prevailed over a longer period. However, the neighbouring sediment core SUP 6 shows river-dominated deposits from the small tributary valley (Figs. 1, 12). 
In contrast, the area west of the Supsa fan, around the modern river mouth, reveals a different stratigraphy. In the sediment core SUP 7 (Fig. 2), coarse sand that is most likely of littoral origin dominates, which is reflected by the relatively high $\mathrm{Ca} / \mathrm{K}$ and $\mathrm{Ca} / \mathrm{Fe}$ ratios and the low $\mathrm{Fe}$ contents (Davies et al., 2015). However, the lower sections resemble, to a certain extent, the (fluvial) deposits of the sediment cores taken from the Supsa fan, although the main grain size is coarser and comparable to the fluvial deposits of sediment core PIC 2 in the Rioni catchment. Plus, the sand is better sorted, which indicates littoral relocation and reworking through longshore drift (Folk and Ward, 1957; Hesp, 2002). The location in the PCAs in Fig. 10 confirms the different composition and deposition. Conditions gradually change upwards, documenting the increasing influence of the Supsa River at the site of SUP 7.

Considering the sediment successions at all the investigated sites we can assume that already before $3000 \mathrm{BCE}$ the research area was already characterized by standing water bodies, likely related to lagoonal environments with finegrained sediments, separated from the open sea by a continuously evolving beach barrier complex. Due to continued riverine sediment input, the lagoons silted up (Berkun et al., 2015) and extended peat bogs formed landwards of the beach ridges. Comparable processes are known from the central Kolkheti lowlands (Laermanns et al., 2017a), as well as from areas further south (Connor et al., 2007; de Klerk et al., 2009). The formation of the Supsa fan has advanced at least since the third millennium BCE, first to the north and later to the west.

\subsection{Human occupation}

Traces of human occupation in the research area can be found in sediment core SUP 10, where the entire layer between 7.51 and $6.56 \mathrm{~m}$ b.s. is full of brick fragments, ceramic remains and charcoal fragments. Obviously, a human settlement existed at or close to this coring site. The radiocarbon ages from the uppermost part of the layer below and the uppermost part of the archaeological stratum, indicate an occupation between 1893-1701 BCE and 778-990 CE (Table 1). The huge age gap within a rather small vertical distance could have been caused by the removal of sediments at the beginning and during the settlement periods. Although the homogeneity of the brick fragments hints at a same origin, it remains unclear if this settlement is of Colchian, Greek or Roman and/or Byzantine origin. In any case, besides the artefacts, the geochemical evidence, namely the sharp increase in $\mathrm{Cu}$ and $\mathrm{Zn}$ values, confirms human activities.

The area of the findings is located between the present shoreline in the west and the northern part of the Supsa fan in the east. This suggests that ancient people settled in the vicinity of the swampy but fertile back-barrier areas, which had been built up by alluvial deposits since at least ca. 2000 BCE (in the case of the SUP 10 site). According to the radio- carbon ages, the gradual shift to a floodplain environment was completed between the 9th and the 11th centuries CE (Figs. 5, 6). Such settlement locations are known from different sites along the Colchian coast, e.g. close to Ureki (Miron and Orthmann, 1995; Gamkrelidze, 2012) or near Kobuleti, where the ancient settlement of Ispani was situated in a similar back-barrier position (Connor et al., 2007; de Klerk et al., 2009); it was later covered by sands.

\section{Conclusions}

Based on the analysis of eight sediment cores a significant landscape change could be proven for the Supsa delta fan and the adjacent areas on the Colchian plain. By using a combination of sedimentological and geochemical parameters, different depositional facies were identified. Their succession reflects the palaeoenvironmental evolution of the area over the last 6000 years. The southern part of the Colchian plain underwent a similar morphogenesis as the areas of the Rioni and other rivers further north (Laermanns et al., 2017a). Although the complex setting of the delta forms a challenging geo-archive, several general trends can be assumed.

After the deceleration of the postglacial sea-level rise around 7000 years ago (Brückner et al., 2010), deltaic progradation became the dominant landscape-forming coastal process (Anthony et al., 2014). In the research area, a beach barrier complex evolved, which led to the formation of extended lagoons. Thus, the area was separated from the open sea by longshore-transported sediments. The Supsa River debouched into this vast lagoon and later floodplain environment. It has formed a remarkable alluvial fan at least since the third millennium BCE. This fan stands out with its elevated relief and a sediment stratigraphy that can well be differentiated from the Rioni-dominated deposits of the Colchian plain by grain-shape characteristics and geochemical parameters. The beach barrier complex first developed with material that had been eroded from cliff sections to the south and later also by sediments that originated from the Rioni and the Supsa rivers.

The indicated sea-level evolution must be considered with caution due to limited information about subsidence and compaction rates, the complex delta setting, and only a few index points. Nevertheless, an overall continuous rise is suggested, and the sea-level trend resembles the RSL curves from the Taman Peninsula (Fouache et al., 2012) and the central parts of the Colchian plain (Laermanns et al., 2017a). However, considering the mentioned challenges, our results should rather be taken as an indication for the sea-level trend, not as a sea-level curve.

Data availability. All data presented in this study were collected, analysed, and interpreted by the authors and are published here. If single amounts of concentrations are not given in tables, they are shown in the graphs (e.g. Fig. 5) so values are publicly accessible. 
For further information please see the dissertation of Hannes Laermanns which is accessible at https://kups.ub.uni-koeln.de/9129/ (last access: 26 June 2019).

Author contributions. All authors and co-authors have approved the final version of the paper and agreed to submission. All authors and co-authors substantially contributed to the presented research. HL, DK, GK, LN, and ME contributed to fieldwork and lab work. HL designed the study, and HL, SMM, DK, SO, and HB interpreted the data. Finally, HL wrote the manuscript with contributions of GK. The paper was amended and corrected by all co-authors.

Competing interests. The authors declare that they have no conflict of interest.

Acknowledgements. Hannes Laermanns gratefully acknowledges the funding of his PhD project by the Heinrich Böll Foundation and by the Graduate School of Geosciences (GSGS) of the University of Cologne. He also thanks the Albertus Magnus Graduate Center (University of Cologne) for funding his research stay at the Université de Franche-Comté in Besançon. We thank the colleagues and students from the Ilia State University and Javakishvili University at Tbilisi, who were involved in fieldwork in 2013 and 2015, for their scientific, administrative and logistical help, as well as for providing accommodation at the Grigoleti Marine Research Centre of the Ilia State University during fieldwork.

Financial support. This research has been supported by the Heinrich Böll Foundation (grant no. P106171 awarded to Hannes Laermanns).

\section{References}

Adamia, S., Zakariadze, G., Chkhotua, T., Sadradze, N., Tsereteli, N., Chabukiani, A., and Gventsadze, A.: Geology of the Caucasus: A Review, Turkish Journal of Earth Sciences, 20, 489-544, 2011.

AG Boden: Bodenkundliche Kartieranleitung, Hannover, Germany, 2005.

Anthony, E. J., Marriner, N., and Morhange, C.: Human influence and the changing geomorphology of Mediterranean deltas and coasts over the last 6000 years: From progradation to destruction phase?, Earth-Sci. Rev., 139, 336-361, 2014.

Arnaud-Fassetta, G., Carre, M.-B., Marocco, R., Maselli Scotti, F., Pugliese, N., Zaccaria, C., Bandelli, A., Bresson, V., Manzoni, G., Montenegro, M.E., Morhange, C., Pipan, M., Prizzon, A., and Siché, I.: The site of Aquileia (northeastern Italy): example of fluvial geoarchaeology in a Mediterranean deltaic plain, Géomorphologie, 4, 227-246, 2003.

Arslanov, K. A., Dolukhanov, P. M., and Gei, N. A.: Climate, Black Sea levels and human settlements in Caucasus Littoral 50000 9000 BP, Quaternary Int., 167-168, 121-127, 2007.

Arz, H. W., Pätzold, J., and Wefer, G.: Correlated millennial-scale changes in surface hydrography and terrigenous sediment yield inferred from last-glacial marine deposits off Brazil, Quaternary Res., 50, 157-166, 1998.

Avdeev, B. and Niemi, N. A.: Rapid Pliocene exhumation of the central Greater Caucasus constrained by low-temperature thermochronometry, Tectonics, 30, 1-16, 2011.

Balabanov, I. P.: Holocene sea-level changes of the Black Sea, in: The Black Sea Flood question: Changes in coastline, climate and human settlement, edited by: Yanko-Hombach, V., Gilbert, A. S., Panin, N., and Dolukhanov, P., Springer, Dordrecht, the Netherlands, 711-730, 2007.

Barsch, H., Billwitz, K., and Bork, H.: Arbeitsmethoden in der Physiogeographie und Geoökologie, Klett-Perthes, Gotha, Germany, 2000.

Bazhenov, M. L. and Burtman, V. S.: Eocene paleomagnetism of the Caucasus (southwest Georgia): Oroclinal bending in the Arabian syntaxis, Tectonophysics, 344, 247-259, 2002.

Berkun, M., Aras, E., and Akdemir, U.: Water runoff, sediment transport and related impacts in the southeastern Black Sea rivers, Environ. Eng. Manag. J., 14, 781-791, 2015.

Blaauw, M. and Christen, J. C.: Flexible paleoclimate age-depth models using an autoregressive gamma process, Bayesian Analysis, 6, 457-474, 2011.

Blair, T. C. and McPherson, J. G.: Alluvial fans and their natural distinction from rivers based on morphology, hydraulic processes, sedimentary processes, and facies assemblages, J. Sediment. Res., A64, 450-489, 1994.

Blott, S. J. and Pye, K.: Technical communication, GRADISTAT: A grain size distribution and statistics package for the analysis of unconsolidated sediments, Earth Surf. Processes Landf., 26, 1237-1248, 2001.

Bolikhovskaya, N. S., Porotov, A. V., Richards, K., Kaitamba, M. D., Faustov, S. S., and Korotaev, V. N.: Detailed reconstructions of Holocene climate and environmental changes in the Taman Peninsula (Kuban River delta region) and their correlation with rapid sea-level fluctuations of the Black Sea, Quaternary Int., 465, 22-36, 2018.

Borůvka, L., Vacek, O., and Jehlička, J.: Principal component analysis as a tool to indicate the origin of potentially toxic elements in soils, Geoderma, 128, 289-300, 2005.

Box, E. O., Fujiwara, K., Nakhutsrishvili, G., Zazanashvili, N., Liebermann, R. J., and Miyawaki, A.: Vegetation and landscape of Georgia (Caucasus) as a basis for landscape restoration, Bulletin of the Institute of Environmental Science and Technology, Yokohama National University, 26, 69-102, 2000.

Braund, D.: Georgia in Antiquity: a history of Colchis and Transcaucasian Iberia, 550 BC-AD 562, Oxford University Press, 359 pp., Oxford, UK, 1994.

Brückner, H., Müllenhoff, M., Handl, M., and van der Borg, K.: Holocene landscape evolution of the Büyük Menderes alluvial plain in the environs of Myous and Priene (Western Anatolia, Turkey), Ann. Geomorphology, 127, 47-65, 2002.

Brückner, H., Kelterbaum, D., Marunchak, O., Porotov, A. and Vött, A.: The Holocene sea level story since $7500 \mathrm{BP}-$ lessons from the Eastern Mediterranean, the Black and the Azov Seas, Quaternary Int., 225, 160-179, 2010.

Brückner, H., Herda, A., Müllenhoff, M., Rabbel, W., and Stümpel, H.: On the Lion Harbour and other harbours in Miletos: recent historical, archaeological, sedimentological, and geophysical re- 
search, Proceedings of the Danish Institute at Athens, 7, 49-103, Aarhus, Denmark, 2014.

Brückner, H., Herda, A., Kerschner, M., Müllenhoff, M., and Stock, F.: Life cycle of estuarine islands - From the formation to the landlocking of former islands in the environs of Miletos and Ephesos in western Asia Minor (Turkey), J. Archaeol. Sci. Reports, 12, 876-894, 2017.

Bungenstock, F. and Weerts, H. J. T.: The high-resolution Holocene sea-level curve for Northwest Germany: global signals, local effects or data-artefacts?, Int. J. Earth Sci., 99, 1687-1706, 2010.

Bungenstock, F. and Weerts, H. J. T.: Holocene relative sea-level curves for the German North Sea coast, Int. J. Earth Sci., 101, 1083-1090, 2012.

Carozza, J.-M., Puig, C., Odiot, T., Valette, P., and Passarius, V.: Geoarchaeological insight in the Tech basin (Roussillon, Gulf of Lion, Western Mediterranean), Quaternary Int., 266, 94-104, 2011.

Connor, S., Thomas, I., and Kvavadze, E.: A 5600-yr history of changing vegetation, sea levels and human impacts from the Black Sea coast of Georgia, The Holocene, 17, 25-37, 2007.

Cuven, S., Francus, P., and Lamoureux, S.: Mid to Late Holocene hydroclimatic and geochemical records from the varved sediments of East Lake, Cape Bounty, Canadian High Arctic, Quaternary Sci. Rev., 30, 2651-2665, 2011.

Davies, S. J., Lamb, H. F., and Roberts, S. J.: Micro-XRF Core Scanning in Palaeolimnology: Recent Developments, in: MicroXRF Studies of Sediment Cores, edited by: Croudace, I. W. and Rothwell, R. G., Springer Nature, Switzerland, 189-226, 2015.

De Klerk, P., Haberl, A., Kaffke, A., Krebs, M., Matchutadze, I., Minke, M., Schulz, J., and Joosten, H.: Vegetation history and environmental development since ca $6000 \mathrm{cal}$ yr BP in and around Ispani 2 (Kolkheti lowlands, Georgia), Quaternary Sci. Rev., 28, 890-910, 2009.

Delile, H., Mazzini, I. Blichert-Toft, J., Arnaud-Godet, F., Salomon, F., and Albarède, F.: Geochemical investigation of a sediment core from the Trajan basin at Portus, the harbor of ancient Rome, Quaternary Sci. Rev., 87, 34-45, 2014.

Denk, T., Frotzler, N., and Davitashvili, N.: Vegetational patterns and distribution of relict taxa in humid temperate forests and wetlands of Georgia (Transcaucasia), Biol. J. Linn. Soc., 72, 287$332,2000$.

Dhont, D. and Chorowicz, J.: Review of the neotectonics of the Eastern Turkish-Armenian Plateau by geomorphic analysis of digital elevation model imagery, Int. J. Earth Sci., 95, 34-49, 2006.

Dingler, J. R.: Beach processes, in: Encyclopedia of Coastal Sciences, edited by: Schwartz, M. L., Springer, Dordrecht, the Netherlands, 161-168, 2005.

Dirix, K., Muchez, P., Degryse, P., and Poblome, J.: Spatial distribution of elemental enrichments around archaeological sites: Insights from the ancient city of Sagalassos in Southwest Turkey, Geoarchaeology, 31, 34-48, 2015.

Dung, T. T. T., Cappuyns, V., Swennen, R., and Phung, N. K.: From geochemical background determination to pollution assessment of heavy metals in sediments and soils, Reviews in Environmental Science and Biotechnology, 12, 335-353, 2013.

Dunne, T. and Aalto, R. E.: Larger River Floodplains, in: Fluvial Geomorphology, edited by: Wohl, E., 9, 645-678, 2013.
Eamer, J. B. R., Shugar, D. H., Walker, I. J., Lian, O. B., and Neudorf, C. M.: Distinguishing depositional setting for sandy deposits in coastal landscapes using grain shape, J. Sediment. Res., 87, 1-11, 2017.

Eppelbaum, L. and Khesin, B.: Geophysical Studies in the Caucasus. Lecture Notes in Earth System Sciences, Springer, Berlin, Heidelberg, Germany, 2012.

Erb-Satullo, N., Gilmour, B., and Khakhutaishvili, N.: Late Bronze and Early Iron Age copper smelting technologies in the South Caucasus: the view from ancient Colchis c. 1500-600 BC, J. Archaeol. Sci., 49, 147-159, 2014.

Erginal, A. E., Ekinci, Y. L., Demirci, A., Bozcu, M., Ozturk, M. Z., Avciglu, M., and Oztura, E.: First record of beachrock on Black Sea coast of Turkey: Implications for Late Holocene sea-level fluctuations, Sediment. Geol., 294, 294-302, 2013.

Flaux, C., El-Assal, M., Shaalan, C., Marriner, N., Morhange, C., Torab, M., Goiran, J. P., and Empereur, J. Y.: Geoarchaeology of Portus Mareoticus: Ancient Alexandria's lake harbour (Nile Delta, Egypt), J. Archaeol. Sci., 13, 669-681, 2017.

Folk, R. L. and Ward, W. C.: Brazos river bar: A study in the significance of grain size parameters, J. Sediment. Petrol., 27, 3-26, 1957.

Forte, A., Cowgill, E., and Whipple, K. X.: Transition from a singly vergent to doubly vergent wedge in a young orogeny: The Greater Caucasus, Tectonics, 33, 2077-2101, 2014.

Fouache, E., Kelterbaum, D., Brückner, H., Lericolais, G., Porotov, A., and Dikarev, V.: The Late Holocene evolution of the Black Sea - a critical view on the so-called Phanagorian regression, Quaternary Int., 266, 162-174, 2012.

Gamkrelidze, G.: Stress vector orientations and movement of the Earth's crust of the territory of Georgia on the neotectonic stage, Bulletin of the Georgian Academy of Science, 158, 284-287, 1998.

Gamkrelidze, G.: Researches in the Iberia-Colchology (History and Archaeology of ancient Georgia), Georgian National Museum Tbilisi, Georgia, 2012.

Giaime, M., Marriner, N., and Morhange, C.: Evolution of ancient harbours in deltaic contexts: A geoarchaeological typology, Earth-Sci. Rev., 191, 141-167, 2019.

Giosan, L., Donnelly, J. P., Filip, F., Ovejanu, I., VespremeanuStroe, A., Vespremeanu, E., and Duller, G. A. T.: Young Danube delta documents stable Black Sea level since the middle Holocene: Morphodynamic, paleogeographic, and archaeological implications, Geology, 34, 757-760, 2006.

Giosan, L., Filip, F., and Constantinescu, S.: Was the Black Sea catastrophically flooded in the early Holocene?, Quaternary Sci. Rev., 28, 1-6, 2009.

Goiran, J. P., Salomon, F., Mazzini, I., Bravard, J. P., Pleuger, E., Vittori, C., Boetto, G., Christiansen, J., Arnaud, P., Pellegrino, A., Pepe, C., and Sadori, L.: Geoarchaeology confirms location of the ancient harbour basin of Ostia (Italy), J. Archaeol. Sci., 41, 389-398, 2014.

Gugushvili, V., Popkhadze, N., Beridze, T., and Khutsishvili, S.: Sources of base, precious and rare metals during the Tethyan Phanerozoic evolution of the Caucasus and Pontides, in: Proceedings of the XIX CBGA Congress, Thessaloniki, School of Geology, Aristotle University of Thessaloniki, Special vol. 100, 333-341, 2010. 
Haghani, S., Leroy, S., Khdir, S., Kabiri, K., Beni, A. N., and Lahijani, H. A. K.: An early 'Little Ice Age' brackish water invasion along the south coast of the Caspian Sea (sediment of Langarud wetland) and its wider impacts on environment and people, The Holocene, 26, 3-16, 2015.

Hammer, Ø., Harper, D. A. T., and Ryan, P. D.: PAST: Paleontological Statistics Software Package for Education and Data Analysis, Palaeontol. Electron., 4, 9-11, 2001.

Heiri, O., Lotter, A., and Lemcke, G.: Loss on ignition as a method for estimating organic and carbonate content in sediments: reproducibility and comparability of results, J. Paleolimnol., 25, 101-110, 2001.

Herda, A., Brückner, H., Müllenhoff, M., and Knipping, M.: From the Gulf of Latmos to Lake Bafa: On the history, geoarchaeology, and palynology of the lower Maeander Valley at the foot of the Latmos Mountains, Hesperia, The Journal of the American School of Classical Studies at Athens, 88, 1-86, 2019.

Hesp, P.: Foredunes and blowouts: initiation, geomorphology and dynamics, Geomorphology, 48, 245-268, 2002.

Hijmans, R. J., Cameron, S. E., Parra, J. L., Jones, P. G., and Jarvis, A.: Very high resolution interpolated climate surface for global land areas, Int. J. Climatol., 25, 1965-1978, 2005.

Horton, B. P. and Shennan, I.: Compaction of Holocene strata and the implications for relative sea-level change on the east coast of England, Geology, 37, 1083-1086, 2009.

Janelidze, Z. and Tatashidze, Z.: Palaeogeographical interpretation of archaeological site of swamps of the Black Sea Coast of Georgia, Bulletin of the Georgian National Academy of Sciences, 4, 159-161, 2010.

Jaoshvili, S.: The rivers of the Black Sea, EEA Technical report 71, European Environmental Agency, Copenhagen, 2002.

Joosten, H., Kaffke, A., and Matchutadze, I.: The mires of the Kolkheti lowlands (Georgia), IMCG Newsletter, 2003/3, 19-23, 2003.

Kasper-Zubillaga, J. J., Dickinson, W. W., Carranza-Edwards, A., and Hronelas-Orozco, Y.: Petrography of quartz grains in beach and dune sands of Northland, North Island, New Zealand, New Zealand Journal of Geology and Geophysics, 48, 649-660, 2005.

Kelterbaum, D., Brückner, H., Porotov, A., Schlotzhauer, U., and Zhuravlev, D.: Geoarchaeology of Taman Peninsula (SW Russia) - the example of the ancient Greek settlement of Golubitskaya 2, Die Erde, 142, 235-258, 2011.

Kelterbaum, D., Brückner, H., Dikarev, V., Gerhard, S., Pint, A., Porotov, A., and Zin'ko, V.: Palaeogeographic changes at Lake Chokrak on the Kerch Peninsula, Ukraine, during the Mid- and Late-Holocene, Geoarchaeology, 27, 206-219, 2012.

Khakhutaishvili, D. A.: The Manufacture of Iron in Ancient Colchis, Archaeopress, Oxford, UK, 2009.

Khakhutaishvili, N.: An ancient Colchian center of iron metallurgy at Chorokhi: excavations in 2001, in: Archaeology in Southern Caucasus: Perspectives from Georgia, edited by: Sagona, A. and Abramashvili, M., Peters, Leuven, Belgium, 397-405, 2008.

Korotaev, G., Oguz, T., Nikiforov, A., and Koblinsky, C.: Seasonal, interannual, and mesoscale variability of the Black Sea upper layer circulation derived from altimeter data, J. Geophys. Res., 108, 19.1-19.15, 2003.

Kraft, J. C., Rapp, G., Kayan, İ., and Luce, J. V.: Harbor areas at ancient Troy: Sedimentology and geomorphology complement Homer's Iliad, Geology, 31, 163-166, 2003.
Kujau, A., Nürnberg, D., Zielhofer, C., Bahr, A., and Röhl, U.: Mississippi River discharge over the last $\sim 560000$ years - indications from X-ray fluorescence core-scanning, Palaeogeogr. Palaeocl., 298, 311-318, 2010.

Laermanns, H., Kelterbaum, D., May, S. M., Elashvili, M., Opitz, S., Hülle, D., Rölkens, Verheul, J., Riedesel, S., and Brückner, H.: Mid- to Late Holocene landscape changes in the Rioni Delta area (Kolkheti lowlands, W Georgia), Quaternary Int., 465, 8598, 2017a.

Laermanns, H., Kirkitadze, G., May, S. M., Kelterbaum, D., Opitz, S., Heisterkamp, A., Basilaia, G., Elashvili, M., and Brückner, H.: Bronze Age settlement mounds on the Colchian plain at the Black Sea coast of Georgia - a geoarchaeological perspective, Geoarchaeology, 33, 453-469, 2017 b.

Lario, J., Zazo, C., Goy, J. L., Dabrio, C. J., Borja, F., Silva, P. G., Sierro, F., González, A., Soler, V., and Yill, E.: Changes in the sedimentation trends in SW Iberia Holocene estuaries (Spain), Quaternary Int., 93-94, 171-176, 2002.

Lordkipanidze, D., Jashashvili, T., Vekua, A., Ponce de León, M., Zollikofer, C., Rightmire, G. P., Pontzer, H., Ferring, R., Oms, O., Tappen, M., Bukhsianidze, M., Agusti, J., Kahlke, R., Kiladze, G., Martinez-Navarro, B., Mouskhelishvili, A., Nioradze, M., and Rook, L.: Postcranial evidence from early Homo from Dmanisi, Georgia, Nature, 449, 305-310, 2007.

Lordkipanidze, O.: Das alte Kolchis und seine Beziehungen zur griechischen Welt vom 6. zum 4. Jh. v. Chr., in: XENIA - Konstanzer Althistorische Vorträge und Forschungen, 14, edited by: Schuller, W., Konstanz, Germany, 49 pp., 1985.

Lordkipanidze, O.: Archäologie in Georgien. Von der Altsteinzeit zum Mittelalter, VCH Verlagsgesellschaft mbH, Weinheim, Germany, 1991.

Marriner, N. and Morhange, C.: Geoscience of ancient Mediterranean harbours, Earth-Sci. Rev., 80, 137-194, 2007.

Marriner, N., Morhange, C., and Goiran, J. P.: Coastal and ancient harbour geoarchaeology, Geology Today, 26, 21-27, 2010.

Martin-Puertas, C., Valero-Garcés, B., Mata, M. P., Moreno, A., Giralt, S., Martinez-Ruiz, F., and Jimenéz-Espejo, F.: Geochemical processes in a Mediterranean lake: a high-resolution study of the last 4,000 years in Zoñar Lake, southern Spain, J. Paleolimnol., 46, 405-421, 2011.

Meyers, P. A. and Teranes, J. L.: Sediment organic matter, in: Tracking Environmental Change Using Lake Sediments, edited by: Last, W. M. and Smol, J. P., Kluwer Academic Publishers, Dordrecht, the Netherlands, 239-269, 2001.

Miron, A. and Orthmann, W.: Unterwegs zum Goldenen Vlies - archäologische Funde aus Georgien, Museum für Vor- und Frühgeschichte Saarbrücken, Saarbrücken, 1995.

Mitchell, J. and Westaway, R.: Chronology of Neogene and Quaternary uplift and magmatism in the Caucasus: constraints from KAr dating of volcanism in Armenia, Tectonophysics, 304, 157186, 1999.

Nikolaishvili, D. A., Elizbarashvili, N., and Meladze, G. G.: Evaluation of degree of landscape's anthropogenic transformation (landscapes of Georgia), Procedia - Social and Behavioral Sciences, 19, 547-555, 2015.

North, C. P. and Davidson, S. K.: Unconfined alluvial flow processes: recognition and interpretation of their deposits, and the significance for palaeogeographic reconstruction, Earth-Sci. Rev., 111, 199-223, 2012. 
Okrostsvaridze, A., Gagnidze, N., and Akimidze, K.: A modern field investigation of the mythical "gold sands" of the ancient Colchis Kingdom and "Golden Fleece" phenomena, Quaternary Int., 409, 61-69, 2016.

Oonk, S., Slomp, C. P., and Huisman, D. J.: Geochemistry as an aid in archaeological prospection and site interpretation: Current issues and research directions, Archaeol. Prospect., 16, 35-51, 2009.

Pavlopoulos, K., Karkanas, P., Triantaphyllou, M., Karymbalis, E., Tsourou, T., and Palyvos, N.: Paleoenvironmental evolution of the coastal plain of Marathon, Greece, during the Late Holocene: Depositional environment, climate, and sea level changes, J. Coast. Res., 22, 424-438, 2006.

Pirazzoli, P. A.: Sea-level Changes. The Last 20,000 Years, Wiley and Sons, Chichester, UK, 1996.

Rayfield, D.: Edge of Empires: A History of Georgia, Reaktion Books, London, UK, 2013.

Reilinger, R., McClusky, S., Vernant, P., Lawrence, S., Ergintav, S., Cakmak, R., Ozener, H., Kadirov, F., Guliev, I., Stepanyan, R., Nadariya, M., Hahubia, G., Mahmoud, S., Sakr, K., Arrajehi, A., Paradissis, D., Al-Aydrus, A., Prilepin, M., Guseva, T., Evren, E., Dmitrotsa, A., Filikov, S. V., Gomez, F., Al-Ghazzi, R., and Karam, G.: GPS constraints on continental deformation in the Africa-Arabia-Eurasia continental collision zone and implications for the dynamics of plate interactions, J. Geophys. Res., 111, 405-411, 2006.

Reimer, P. J., Bard, E., Bayliss, A., Beck, J. W., Blackwell, P. G., Bronk Ramsey, C., Buck, C. E., Cheng, H., Edwards, R. L., Friedrich, M., Grootes, P. M., Guilderson, T. P., Haflidason, H., Hajdas, I., Hatté, C., Heaton, T. J., Hogg, A. G., Hughen, K. A., Kaiser, K. F., Kromer, B., Manning, S. W., Niu, M., Reimer, R. W., Richards, D. A., Scott, E. M., Southon, J. R., Turney, C., and van der Plicht, J.: InterCal13 and Marine 13 radiocarbon age calibration curves 0-50,000 years cal BP, Radiocarbon, 55, 18691887, 2013.

Ryan, W. B. F.: Status of the Black Sea Flood Hypothesis, in: The Black Sea Flood Question, edited by: Yanko-Hombach, V., Gilbert, A. S., Panin, N., and Dolukhanov, P. M., Springer, Dordrecht, the Netherlands, 63-88, 2007.

Sadzradze, V., Davlianidze, R., and Murvanidze, B.: Archaeological investigation of Supsa terminal and adjacent area, Pipeline Archaeology, 1, 104-115, 1999.

Sens, U.: Kulturkontakt an der östlichen Schwarzmeerküste, in: Schriften des Zentrums für Archäologie und Kulturgeschichte des Schwarzmeerraumes, 15, edited by: Bertemes, F. and Furtwängler, A., Beier \& Beran, Stuttgart, Germany, 2009.

Sosson, M., Rolland, Y., Müller, C., Danelian, T., Mekonyan, R., Kekelia, S., Adamia, S., Babazadeh, V., Kangarli, T., Avagyan, A., Galoyan, G., and Mosar, J.: Subduction, obduction and collision in the Lesser Caucasus (Armenia, Azerbaijan, Georgia) new insights, Geological Society, London Special Publications, 340, 329-352, 2010.
Stock, F., Pint, A., Horejs, B., Ladstätter, S., and Brückner, H.: In search of the harbours - new evidence of Late Roman and Byzantine harbours of Ephesus, Quaternary Int., 312, 57-69, 2013.

Stock, F., Kerschner, M., Kraft, J. C., Pint, A., Frenzel, P., and Brückner, H.: The palaeogeographies of Ephesos (Turkey), its harbours, and the Artemision - a geoarchaeological reconstruction for the timespan 1500-300 BC, Ann. Geomorphol., 58, 3366, 2014.

Stock, F., Knipping, M., Pint, A., Ladstätter, S., Delile, H., Heiss, A., Laermanns, H., Mitchell, P., Ployer, R., Steskal, M., Thanheiser, U., Urz, R., Wennrich, V., and Brückner, H.: Human impact on Holocene sediment dynamics in the Eastern Mediterranean - the example of the Roman harbour of Ephesus, Earth Surf. Processes Landf., 41, 980-996, 2016.

Stuiver, M. and Reimer, P.: Extended ${ }^{14} \mathrm{C}$ data base and revised Calib 3.0 ${ }^{14} \mathrm{C}$ age calibration program, Radiocarbon, 35, 215230, 1993.

Törnqvist, T. E., Wallace, D. J., Storms, J. E. A., Wallinga, J., Dam, R. L., Blaauw, M., Derksen, M. S., Klerks, C. J. W., Meijneken, C., and Snijders, E. M. A.: Mississippi Delta subsidence primarily caused by compaction of Holocene strata, Nat. Geosci., 1, 173-176, 2008.

Turney, C., Canti, M., Branch, N., and Clark, P.: Environmental archaeology: theoretical and practical approaches, Routledge, London, UK, 2005.

Vött, A.: Relative sea level changes and regional tectonic evolution of seven coastal areas in NW Greece since the mid-Holocene, Quaternary Sci. Rev., 26, 894-919, 2007.

Vött, A., Schriever, A., Handl, M., and Brückner, H.: Holocene palaeogeographies of the central Acheloos River delta (NW Greece) in the vicinity of the ancient seaport Oiniadai, Geodinamica Acta, 20, 241-256, 2007.

Yilmaz, A., Adamia, S., and Y1lmaz, H.: Comparisons of the suture zones along a geotraverse from the Scythian Platform to the Arabian Platform, Geosci. Frontiers, 5, 855-875, 2013.

Zhang, C. and Mischke, S.: A Late glacial and Holocene lake record from the Nianbaoyeze Mountains and inferences of lake, glacier and climate evolution on the eastern Tibetan Plateau. Quaternary Sci. Rev., 28, 1970-1983, 2009.

Zhang, C., Wang, L., Li, G., Dong, S., Yang, J., and Wang, X.: Grain size effect on multi-element concentrations in sediments from the intertidal flats of Bohai Bay, China, Appl. Geochem., 17, 59-68, 2002. 